\title{
Nasal protein profiles in work-related asthma caused by different exposures
}

\section{Suojalehto, Hille}

2018-03

Suojalehto , H , Wolff , H , Lindström , I \& Puustinen , A 2018 , ' Nasal protein profiles in work-related asthma caused by different exposures ' , Allergy : European journal of allergy pÿand clinical immunology , vol. 73 , no. 3 , pp. 653663 . https://doi.org/10.1111/all.13325

http://hdl.handle.net/10138/325653

https://doi.org/10.1111/all.13325

unspecified

acceptedVersion

Downloaded from Helda, University of Helsinki institutional repository.

This is an electronic reprint of the original article.

This reprint may differ from the original in pagination and typographic detail.

Please cite the original version. 
Nasal protein profiles in work-related asthma caused by different exposures

Hille Suojalehto ${ }^{1} \mathrm{MD}$, PhD, Irmeli Lindström ${ }^{1} \mathrm{MD}$, PhD, Henrik Wolff ${ }^{2} \mathrm{MD}, \mathrm{PhD}$, Anne Puustinen ${ }^{3,4} \mathrm{PhD}$

${ }^{1}$ Occupational Medicine, Finnish Institute of Occupational Health, Helsinki, Finland

${ }^{2}$ Work environment laboratories, Finnish Institute of Occupational Health, Helsinki, Finland

${ }^{3}$ Unit of Systems Toxicology, Finnish Institute of Occupational Health, Helsinki, Finland

${ }^{4}$ Verifin, Department of Chemistry, University of Helsinki, Finland

Hille Suojalehto

Finnish Institute of Occupational Health

Fl-00251 Helsinki, Finland

email: hille.suojalehto@ttl.fi

Phone: +358 304742545

Fax: +358 304742009

Short title: Nasal protein profiles in work-related asthma

Key words: exposure, isocyanate, proteomics, work-related asthma, welding

Word count: 3561

This work was supported by grant from the Finnish Work Environment Fund (project No. 109365). 


\section{Abstract}

Background The mechanisms of work-related asthma are incompletely delineated. Nasal cell samples may be informative about processes in the lower airways. Our aim was to determine the nasal protein expression profiles of work-related asthma caused by different kind of exposures.

Methods We collected nasal brush samples from 82 non-smoking participants, including healthy controls and work-related asthma patients exposed to 1) protein allergens, 2) isocyanates, and 3) welding fumes the day after relevant exposure. The proteome changes in samples were analysed by two-dimensional difference gel electrophoresis and the differentially regulated proteins found were identified by mass spectrometry. Immunological comparison was carried out using Western blot.

Results We detected an average of 2500 spots per protein gel. Altogether 228 protein spots were chosen for identification, yielding 77 different proteins. Compared to the controls exposure to protein allergens had the largest effects on the proteome. Hierarchical clustering revealed that protein allergen and isocyanate related asthma had similar profiles, whereas asthma related to welding fumes differed. The highly overrepresented functional categories in the asthma groups were defence response, protease inhibitor activity, inflammatory and calcium signalling, complement activation, and cellular response to oxidative stress. Immunological analysis confirmed the found abundance differences in Galectin 10 and Protein S100-A9 between the groups.

Conclusions Work-related asthma patients exposed to protein allergens and isocyanates elicit similar nasal proteome responses and the profiles of welders and healthy controls were alike. Revealed biological activities of the protein expression changes are associated with allergic inflammation and asthma. 


\section{Introduction}

Occupational exposure can initiate or trigger asthma, leading to the development of different types of work-related asthma (WRA) (1). Protein allergens at workplaces cause asthma via Immunoglobulin E (IgE)-associated mechanisms, which are similar to allergic asthma unrelated to work (2). Asthma associated with isocyanate exposure is often IgE-independent, but the mechanisms are incompletely delineated. Welding fumes and aerosols composed of potentially hazardous metals and gases are also common exposures among WRA patients $(3,4)$. These fumes diminish functionality of local and circulating immune cells but the mechanisms in airway diseases are poorly understood (5).

Asthma and rhinitis commonly coexist and this is also true in WRA. Up to 90\% of WRA patients report work-related rhinitis symptoms (6). Nasal epithelium provides an important physico-chemical and immunological barrier against the different factors targeting lower airways, but the mechanisms explaining the correlations between these diseases are not fully understood. According to the united airway concept, both diseases could be secondary to the same disease mechanisms occurring throughout the respiratory tract (7).

Proteomic approaches offer great potential for the systematic analysis of complex biological airway samples and have the advantage of assessing the presence and abundance of gene products (i.e., proteins), which are functionally relevant to the clinical phenotypes of airway diseases (8). A nasal brush sample (NBS) is a relatively non-invasive specimen containing proteins secreted from epithelial and inflammatory cells (9). Induced sputum and nasal lavage fluid (NLF), have been applied to characterize proteomic changes in airway diseases (10, 11). The identified proteins in these samples have been mostly identical (12) suggesting that also NBS may be useful in the research of upper airway epithelia and as a surrogate of lower airways.

We assessed the NBS proteome in patients with WRA who were exposed to protein allergens, isocyanates or welding fumes, and in healthy subjects. Our aim was to determine whether the proteomics method could reveal differences between the protein expressions of these groups and to investigate potential reaction mechanisms. Our premise was that nasal samples could reflect the protein profile of the entire airways.

\section{Materials and methods}

\section{Study design and population}

The study population included WRA patients examined at the Finnish Institute of Occupational Health during 2009-2012 (Figure 1). Their asthma diagnosis was confirmed by demonstrating reversible airway obstruction or bronchial hyperresponsiveness. They were exposed at work to 1) protein allergens, 2) isocyanates, or 3) welding fumes. Their asthma symptoms emerged while they were exposed to the occupational agent, and worsened during exposure. The control group comprised healthy men who carried out their military service 19861990 and participated in a follow-up study in 2009 (13). Current smokers were excluded. A subset of samples were used in the proteomic analysis and few found differences were compared both in the whole population and in those excluded from proteomic analysis. In order to analyse representative and homogeneous groups, NBS from eight participants in each group were selected based on clinical symptoms to represent their groups, outliers were not included. The clinical characteristics of these groups are presented in Table S1. The study was 
approved by the ethics committee of Helsinki University Central Hospital (approval number 284/13/03/00/08, 125/13/03/00/09). All participants signed their informed consent.

Methods of clinical tests, controlled exposure to occupational agent as well as induced sputum and nasal brush sample preparation are described in Supplementary material 1.

\section{Two-dimensional differential gel electrophoresis and gel spot protein identification}

For proteomics analysis, $2 \mathrm{ml}$ of NBS supernatant was concentrated. Protein samples were prepared and two-dimensional differential gel electrophoresis (2D-DIGE) was performed, as previously described (12). For protein identification, in-gel digestion was conducted for the chosen gel spots and the resulting peptides were extracted (12) and dried in a vacuum centrifuge. Each peptide mixture was analysed by an automated EASY nanoLC 1000 (Proxeon, Thermo Fisher Scientific Inc., USA) coupled to an electrospray ionization quadrupole orpitrap mass spectrometer (QExactive, Thermo Fisher Scientific Inc., USA). Reverse-phase separation of peptides was carried out using a $75 \mu \mathrm{m} \times 15 \mathrm{~cm}$ Acclaim PepMap100 C18 column (Dionex, Thermo Fisher Scientific Inc., USA) at a flow rate of $300 \mathrm{~nL} / \mathrm{min}$. Peptides were eluted from the column with a linear gradient of $5-35 \%$ solvent B (0.1\% formic acid in $95 \%$ acetonitrile) in 80 minutes. Solvent A was $0.1 \%$ formic acid in $5 \%$ acetonitrile. We searched for the mass fragment spectra obtained in the SwissProt database (www.uniprot.org) against human entries using Proteome Discoverer 1.4 (Thermo Fisher Scientific Inc., USA).

\section{Immunological comparison}

Abundances of Glutathione S-transferase 1 (GSTP1), Galectin 10 (LEG10), Protein S100-A9 (S10A9), and Calcyphosin (CAYP1) were compared by Western blotting in the whole study population using precast 26 -well $12 \%$ Criterion TGX gels (BioRad), as previously described (12). The gel lane was loaded with $10 \mu \mathrm{l}$ of untreated NBS. Primary antibody dilutions were 1:100 for S10A9 (Abcam 24111), 1:10000 for LEG10 (Abcam 157475), 1:2000 for GSTP1 (Abcam 47709) and 1:4400 for CAYP1 (Abcam 188470). Immunoblots were stained with anti-rabbit or anti-mouse peroxidase-conjugated immunoglobulins (1:2000) (Dako Cytomaton) and chemiluminescent HRP-substrate ECL detection reagent (Perkin Elmer). They were visualized by an Image Quant LAS 4000 mini quantitative imager (GE Healthcare Biosciences). ImageQuant TL (GE Healthcare Biosciences) was used to calculate the intensities of the protein bands, which were normalized to the band intensity of a pool containing all samples.

\section{Statistical and bioinformatical analyses}

Continuous variables were expressed as means ( \pm standard deviation) or median (interquartile range) depending on their distribution and categorical values as percentages. Logaritmic transformation was used to attain normal distribution of continuous variables. The differences between the groups were analysed using Student's $t$-test or Anova and Fisher's LSD test for post hoc comparisons. Mann-Whitney U-test or Kruskal-Wallis test or was used when normal distribution was not attained after logarithmic transformation, and Chi-square test for categorical values. We computed Spearman's correlation between continuous values. A p-value of $<0.05$ was considered statistically 
significant. IBM SPSS Statistics for Windows, Version 20.0 (Armonk, NY: IBM Corp.) software was used for analysing the clinical parameters and for correlations. Principal component analysis (PCA) and hierarchical clustering of the identified differentially abundant proteins were performed with DeCyder Extended Data Analysis software (Version 7.0, GE Healthcare), using average linkage and the Euclidean metric as a distance measure. Western blot intensities were statistically analysed using GraphPad Prism 5 software (GraphPad Software).

Ingenuity Pathway Analysis (IPA) (Qiagen), String (string-db.org) and Enrichr (amp.pharm.mssm.edu/Enrichr) were used to investigate interactions, functions and pathways of relevance in the identified proteins.

\section{Results}

\section{Study population}

Table 1 presents the characteristics of 82 participants. Work-exacerbated rhinitis symptoms were reported by 27 (93\%) of the WRA patients in the protein allergen group, $12(100 \%)$ in the isocyanate group, and $11(79 \%)$ in the welding group ( $p=0.139)$. Nonspecific bronchial hyperresponsiveness was detected in $17(59 \%), 4(33 \%), 7(54 \%)$ of the patients of the above groups, respectively $(p=0.333)(n=54)$. Nasal steroid was withdrawn at least three days before sample collection; 12 (22\%) of the WRA patients had used a nasal steroid during the previous four weeks. Positive skin prick tests (SPT) to common environmental allergens were detected more often in the protein allergen group (82\%) than in the isocyanate $(42 \%)$, welding $(43 \%)$ or control (30\%) groups (Table 1$)$. Positive SPT to the occupational allergen of controlled exposure was found in 26 of 27 tested participants in the protein allergen group, but none in the isocyanate or welding group reacted to the isocyanate-albumin conjugate or metal suspension. Similarly, specific IgE to the occupational allergen was detected in 21 of 28 tested participants in the protein allergen group, but in none of the 10 tested in the isocyanate group. Fractional exhaled nitric oxide (FeNO) was highest in the protein allergen group, whereas nasal eosinophil count was biggest in the isocyanate group.

\section{Two-dimensional differential gel electrophoresis (2D-DIGE) differences in protein abundances}

DeCyder software matched on average 2500 spots per DIGE gel, no significant difference was observed between the total number of protein spots of the study groups. 228 protein spots with changed intensity from statistical analysis (Student's $t-$ test $<0.05$, a fold change of $\leq-1.5$ or $\geq 1.5$ ) between groups were identified (Table S2, Figure S1) revealing altogether 77 different proteins (Table 2), as several proteins were identified from multiple gel spots. As many as $95 \%$ of the proteins found are known to have an extracellular location (Gene Ontology (GO):0070062, GO:0005615). In addition to plasma-derived proteins, various nasal epithelium proteins were detectable. Of the identified molecules, 32 were involved in inflammatory responses, 36 in cellular movement, 20 in free radical scavenging, 42 in cell death and survival, and 18 in allergy (Table S3). Calcium binding proteins were also enriched among the proteins identified. Three up-regulated and seven downregulated proteins were common to all the WRA groups. 
Unsupervised classification analyses were applied to the data to obtain an overview of protein abundance patterns. Hierarchical clustering analysis (Figure 2A), in which proteins with similar manifestation profiles are clustered together, showed that the protein patterns from participants with protein and isocyanate WRA resembled each other, and that the patterns in the welding group differed from the other WRA groups. When PCA was applied to the set of all the proteins identified in the nasal epithelium, the groups were positioned into separate quadrants, implying that different types of occupational exposures appear to perturb the global variability of nasal epithelial protein levels (Figure 2B). The PCA of identified protein spots (Figure $2 \mathrm{C}$ ) showed clear separation of the spots to two abundance clusters, similarly to the abundance differences in Figure 2A.

\section{Group-specific differently abundant proteins}

The largest effects on the proteome of nasal epithelium were in the protein allergen group (Tables 2 and S1, Figures 2A and S2), in which 20 proteins were up-regulated and 43 down-regulated in comparison to the healthy controls. Exposure to isocyanates showed changes in 32 proteins and welding in 19 proteins. When WRA groups were compared with each other, the largest proteome differences observed were between the protein allergen and welding groups (45 different proteins). Welding-specific changes were decreased levels of heat shock cognate $71 \mathrm{kDa}$ protein spots, and increased amounts of pyruvate kinase isozymes M1/M2 and Fatty acid binding protein.

Protein S100-A9 abundance was increased in all WRA groups, but protein S100-A8 (S10A8) was identified only for the protein allergen group. Other calcium binding proteins, calcyphosin (CAYP1) and annexins A1 and A2 (ANXA1, 2) had decreased protein levels in the protein allergen and isocyanate groups. The protein allergen group seemed to also contain low levels of annexins 3 and 5.

We identified several proteins involved in the detoxification of reactive oxygen species (Table 2). The catalase level was increased, whereas the levels of glutathione (GSH) synthesis-linked proteins s-formylglutathione hydrolase, glutathione synthetase and adenosylhomocysteinase were diminished, as was the GSH conjugation catalysing enzyme, GSTP1. Peroxiredoxins 1, 2 and 5 (PRDXs) levels were lower in the protein allergen group, and superoxide dismutase (SODC) levels decreased in the protein allergen and isocyanate groups. Changes in the abundancies of thioredoxin and protein disulphide-isomerase, which also belongs to the thioredoxin superfamily, were specific to isocyanate exposure.

\section{Pathways and networks of proteins}

Figure S2 shows the protein association networks of the proteins identified in each WRA group. Mitogen-activated protein kinases (MAPKs) and nuclear factor kappa B (NFKB)-signalling pathways consistently emerged in network searches, including single protein fishes, and were thus added to Figure S3 networks.

Pathways and diseases linked to the observed proteomic changes of the nasal mucosa in the IPA search are presented in Table 3. The reported ethanol degradation pathway, common to the protein allergen and isocyanate groups, is most likely connected to the aldehyde dehydrogenases involved in the metabolism of corticosteroids. The nuclear factor erythroid 2-related, factor 2 (Nrf2)-mediated oxidative stress response pathway is common to protein allergen and isocyanate WRA groups. Nrf2 is a key transcription factor that regulates antioxidant defence in macrophages and epithelial cells (14), and is a component of the GSTP1 interactome (15). Protein-allergen and 
Isocyanate exposed asthma patients experienced more severe nasal symptoms and had a suggestive increase in nasal and sputum eosinophils which may be linked to inflammatory response in Table 3.

\section{Immunological comparison of nasal brush samples}

Several of the identified proteins are associated with allergic reaction mechanisms, among them GSTP1, LEG10 and S100A9, which were selected for further analysis as high quality commercial antibodies were also available for them. The unfamiliar fourth analyte, calcium binding protein CAYP1, may play a role in cellular signaling events.. The Western blot analysis revealed similar abundance differences in a few proteins in the whole study population (Figure 3) and in 50 subjects who were excluded from proteomic analysis (Table S4). The levels of the calcium binding protein S10A9 and T cell proliferation suppressor protein LEG10 were up-regulated in all asthma groups. The oxidative stress defence protein GSTP1 showed a trend of reduction in the protein allergen group in comparison to the control group, whereas there was tendency for decreased levels of CAYP1 in all WRA groups compared to the controls. Abundances of the GSTP1 and CAYP1 proteoforms might vary in opposite directions, and together with the statistically relatively small study population, they could be the underlying causes for the lack of clear group differences.

\section{Associations between protein abundances and clinical parameters}

Protein abundances of GSTP1, LEG10, S10A9 or CAYP1 did not correlate with age, sputum eosinophils, FeNO, nNO or total IgE, whereas moderate correlation was seen between LEG10 and blood eosinophils $(r=0.536, p=0.008)$ as well as S10A9 and FEV $1 / F V C(r=0.438, p=0.017)$. GSTP1 was higher in men ( $p=0.016)$, but no significant gender difference was found in Western blot intensities of GSTP1 ( $p=0.242$ ) or other protein abundances.

\section{Discussion}

Proteomic analysis of NBS is a relatively non-invasive way to evaluate airway inflammation. Hierarchical clustering analysis of the protein abundance patterns of NBS indicated that the nasal protein profile in protein-allergen- and isocyanate-related asthma groups are similar, and differ from those of healthy controls, whereas the welding group pattern bore more resemblance to that of the controls.

Clinical tests targeted to show causal relationship with asthma and occupational exposure (e.g. specific IgE, specific inhalation challenge) may select patients based on disease mechanisms. To avoid this preselection, we studied WRA patients. The vast majority of our WRA patients had concurrent work-aggravated rhinitis symptoms, as others have reported (6). The use of nasal steroids among the three WRA groups ( $p=0.75$ ) during the four previous weeks did not significantly differ, suggesting that steroids had no significant effect on the protein abundances of these groups. Highest FeNO level reflecting Th2-derived inflammation in protein-allergen-related asthma group was similar to pervious findings (16). Isocyanate-related asthma patients had more nasal, but not sputum, eosinophils than other groups. Raulf-Heimsoth et al. detected an increase in sputum eosinophils but not in NLF after a positive isocyanate challenge (17). 
Few studies have reported the proteome of work-related airway diseases. Mörtstedt et al. performed targeted proteomic analyses of NLF before and after a persulfate challenge among hairdressers with bleaching powder-associated rhinitis as compared to healthy hairdressers and atopic subjects (18). They detected changes in proteins related to inflammatory responses and oxidative stress, but the changes were not specific to rhinitis patients. Studies of nasal proteome in seasonal allergic rhinitis have shown a perennial inflammatory response in nasal mucus and lack of adequate reaction to allergens in season (19-21).

Proteomic changes in airway diseases have been characterized from induced sputum and NLF $(10,11)$. The most abundant proteins observed in these biofluids are plasma proteins, which are presumably derived from diffusion across the blood-air barrier (e.g. albumin, transferrins, immunoglobulins, alpha-1-antitrypsin), and interfere with the detection of less abundant proteins (12). NBS has rarely been used to investigate the proteome of patients with respiratory disorders (22). In this study, NBS provided good quality material, which was not distracted by blood derived high abundance proteins.

Protein abundance patterns analysed by hierarchical clustering were similar in protein allergen- and isocyanate-related WRA. IgE-mediated sensitization to isocyanates was not detected, while it was seen to occupational protein allergens in all but one case. This suggests that protein-allergen- and isocyanate-related WRA share non-IgE mediated immunological mechanisms. The welders' profile differed from that of the other WRA groups and controls, proposing different underlying mechanisms.

Our results indicate that the nasal epithelial proteome of the WRA patients is highly enriched in processes related to inflammatory and calcium signalling, free radical scavenging and oxidative stress response, and metabolism. The most relevant signalling networks were through the pathways associated with redox sensitive transcription factors, NFKB and Nfr2, and with MAPKs, which differentially regulate pro-inflammatory cytokine genes and protective antioxidant genes (23-25). Nrf2-deficient mice have a heightened susceptibility to asthma, including elevated oxidative stress, inflammation, mucus, and airway hyperresponsiveness (26). Airway inflammation and remodelling in asthma involves degradation of the extracellular matrix. Among the identified proteases and their inhibitors was Serpin B3, which inhibits inflammation and promotes epithelial proliferation with increased transforming growth factor-beta secretion (27). Several inflammatory defence proteins with both increased and decreased abundance were detected in subjects exposed to protein allergens and isocyanates. LEG10 (aka Charcot-Leyden Crystal (CLC) protein, Eosinophil lysophospholipase) has been associated with eosinophilic inflammation in allergic diseases $(28,29)$ and with the function of regulatory T-cells $(30)$. LEG10 is mainly released from eosinophil granules, but it is also expressed by basophils and some T cells (30). It belongs to the galectin superfamily of lectins (31), although its physiologically relevant carbohydrate ligand is unknown. Further knowledge of this would help us understand its role in inflammatory reactions.

Oxidative stress is important for the pathogenesis of lung damage and for the development of lung fibrosis. Among the various enzymatic and non-enzymatic mechanisms that protect cells and tissues from oxidants, GSH, SODs and PRDXs play a key protective role, especially in the lungs $(32,33)$. A lower level of GSH synthesis enzymes, SODs and PRDXs might induce continuous oxidative stress in the airways. In this study, a decreased abundance of all these proteins was observed in the participants with symptoms on exposure to protein allergens and isocyanates, but not in the welding group, suggesting that the impairment of protection from oxidative stress might play a key role in the pathogenesis of WRA. 
GSTP1 plays a significant role in detoxification processes that regulate inflammatory responses stimulated by xenobiotic and oxidative compounds, and is important in determining susceptibility to asthma. GSTP1 conjugates reduce GSH to electrophilic species, and adduct formation with xenobiotics promotes their elimination, whereas binding to protein thiols causes a reversible posttranslational modification, S-glutathionylation, which protects proteins from irreversible oxidations and can modulate their function (34). GSTP1 gene activation is mainly regulated by Nrf2 (35), and the functional association between GSTP and Nrf2 proteins supports the regulatory role of GSTP in the adaption response to cellular stresses produced in the course of inflammatory and oxidative reactions (15). As in the present study, GSTP was decreased in NLF after the persulphate challenge (18).

$\mathrm{Ca}^{2+}$ signals are important in inflammatory signalling and in the pathophysiology of airway diseases. Calcium-modulated S100 protein family members S10A9 and S10A8 are both among the most abundant proteins in airway cells during chronic inflammation. They may form a calprotectin complex which can induce cell proliferation, apoptosis, inflammation, collagen synthesis, and cell migration. S10A9 alone mediates fibroblast proliferation, increases mucin production, and is involved in NFKB network and inflammasome activation (36), whereas the protective role of $\mathrm{S} 10 \mathrm{~A} 8$ in allergic inflammation is to modulate mast cell activation and eosinophil recruitment, and scavenge the oxidants generated by activated leukocytes (37). Synthesis and activation of CAYP1 is induced by the cAMP cascade (protein kinase A) and CAYP1 may regulate cell proliferation and differentiation $(38,39)$. Interestingly, String DB predicts as functional partners for CAYP1 several MAP kinases, which are activated in response to inflammatory and oxidative stress signals (24). Glucocorticoid regulated annexins interact with cell membrane phospholipids, and are involved in various cellular processes, including endocytosis, exocytosis, membrane-cytoskeletal organization, and migration through the association of partner proteins, including members of the S100 family. ANXA1 is an antiinflammatory protein that plays a critical regulatory role in the development of asthma $(40,41)$, whereas ANXA2 promotes fibrinolysis (42). The roles of ANXA3 and 5 in asthma are largely unknown, but their amounts were reduced in the protein allergen exposure groups.

\section{Conclusions}

Proteome analysis of NBS provides preliminary results regarding the mechanisms of work-related airway diseases in patients exposed to protein allergens, isocyanates and welding fumes. WRA patients exposed to protein allergens and isocyanates showed similar nasal proteome responses, although the specific IgE was found only among patients exposed to protein allergens. The proteome of patients exposed to welding fumes resembled healthy controls. The identified changes in protein expressions of asthma patients reveal biological activities related to airway inflammation, oxidation reduction, tissue matrix turnover, and inflammatory signalling. Our findings provide new possibilities to biomarker research and the development of diagnostic methods of work-related airway diseases.

\section{Acknowledgements}

We warmly thank Risto Voutilainen, Liisa Airaksinen, Sauli Savukoski, Niina Ahonen, Sari Tillander, Outi Fisher, and the nurses for their valuable work. The Finnish Work Environment Fund supported the study. 


\section{Authors' contributions}

All authors participated in conception, design and interpretation of data and approved the final version. HS, AP and IL acquired data, HS and AP analysed data and drafted the article which IL and HW reviewed.

\section{Conflict of interest}

The authors declare no conflict of interest.

\section{References}

1. Malo JL, Vandenplas O. Definitions and classification of work-related asthma. Immunol Allergy Clin North Am 2011;31(4):645-662, v.

2. Lummus ZL, Wisnewski AV, Bernstein DI. Pathogenesis and disease mechanisms of occupational asthma. Immunol Allergy Clin North Am 2011;31(4):699-716, vi.

3. Banga A, Reilly MJ, Rosenman KD. A study of characteristics of Michigan workers with work-related asthma exposed to welding. J Occup Environ Med 2011;53(4):415-419.

4. Hannu T, Piipari R, Tuppurainen M, Nordman H, Tuomi T. Occupational asthma caused by stainless steel welding fumes: a clinical study. Eur Respir J 2007;29(1):85-90.

5. Zeidler-Erdely PC, Erdely A, Antonini JM. Immunotoxicology of arc welding fume: worker and experimental animal studies. J Immunotoxicol 2012;9(4):411-425.

6. Vandenplas O, Van Brussel P, D'Alpaos V, Wattiez M, Jamart J, Thimpont J. Rhinitis in subjects with workexacerbated asthma. Respir Med 2010;104(4):497-503.

7. Castano R, Malo JL. Occupational rhinitis and asthma: where do we stand, where do we go? Curr Allergy Asthma Rep 2010;10(2):135-142.

8. Terracciano R, Pelaia G, Preiano M, Savino R. Asthma and COPD proteomics: current approaches and future directions. Proteomics Clin Appl 2015;9(1-2):203-220.

9. Simoes T, Charro N, Blonder J, Faria D, Couto FM, Chan KC, et al. Molecular profiling of the human nasal epithelium: A proteomics approach. J Proteomics 2011;75(1):56-69.

10. Benson LM, Mason CJ, Friedman O, Kita H, Bergen HR, 3rd, Plager DA. Extensive fractionation and identification of proteins within nasal lavage fluids from allergic rhinitis and asthmatic chronic rhinosinusitis patients. $J$ Sep Sci 2009;32(1):44-56.

11. Gharib SA, Nguyen EV, Lai Y, Plampin JD, Goodlett DR, Hallstrand TS. Induced sputum proteome in healthy subjects and asthmatic patients. J Allergy Clin Immunol 2011;128(6):1176-1184 e1176.

12. Suojalehto $\mathrm{H}$, Kinaret $\mathrm{P}$, Kilpelainen $\mathrm{M}$, Toskala E, Ahonen N, Wolff H, et al. Level of Fatty Acid Binding Protein 5 (FABP5) Is Increased in Sputum of Allergic Asthmatics and Links to Airway Remodeling and Inflammation. PLoS One 2015;10(5):e0127003.

13. Lindström I, Pallasaho P, Luukkonen R, Suojalehto H, Karjalainen J, Lauerma A, et al. Reduced work ability in middle-aged men with asthma from youth--a 20-year follow-up. Respir Med 2011;105(6):950-955.

14. Li N, Alam J, Venkatesan MI, Eiguren-Fernandez A, Schmitz D, Di Stefano E, et al. Nrf2 is a key transcription factor that regulates antioxidant defense in macrophages and epithelial cells: protecting against the proinflammatory and oxidizing effects of diesel exhaust chemicals. J Immunol 2004;173(5):3467-3481.

15. Bartolini D, Galli F. The functional interactome of GSTP: A regulatory biomolecular network at the interface with the Nrf2 adaption response to oxidative stress. J Chromatogr B Analyt Technol Biomed Life Sci 2016;1019:29-44.

16. Lemiere C, S NG, Sava F, D'Alpaos V, Huaux F, Vandenplas O. Occupational asthma phenotypes identified by increased fractional exhaled nitric oxide after exposure to causal agents. J Allergy Clin Immunol 2014;134(5):1063-1067.

17. Raulf-Heimsoth M, Liebig R, Marczynski B, Borowitzki G, Bernard S, Freundt S, et al. Implementation of noninvasive methods in the diagnosis of diisocyanate-induced asthma. Adv Exp Med Biol 2013;788:293-300.

18. Mortstedt H, Ali N, Karedal M, Jacobsson H, Rietz E, Diab KK, et al. Targeted proteomic analyses of nasal lavage fluid in persulfate-challenged hairdressers with bleaching powder-associated rhinitis. J Proteome Res 2015;14(2):860-873.

19. Tomazic PV, Birner-Gruenberger R, Leitner A, Obrist B, Spoerk S, Lang-Loidolt D. Nasal mucus proteomic changes reflect altered immune responses and epithelial permeability in patients with allergic rhinitis. $J$ Allergy Clin Immunol 2014;133(3):741-750. 
20.

Tomazic PV, Birner-Gruenberger R, Leitner A, Spoerk S, Lang-Loidolt D. Seasonal proteome changes of nasal mucus reflect perennial inflammatory response and reduced defence mechanisms and plasticity in allergic rhinitis. J Proteomics 2016;133:153-160.

21. Ndika J, Airaksinen L, Suojalehto H, Karisola P, Fyhrquist N, Puustinen A, et al. Epithelial proteome profiling suggests essential role of interferon-inducible proteins in allergic rhinitis. J Allergy Clin Immunol 2017.

22. Roxo-Rosa M, da Costa G, Luider TM, Scholte BJ, Coelho AV, Amaral MD, et al. Proteomic analysis of nasal cells from cystic fibrosis patients and non-cystic fibrosis control individuals: search for novel biomarkers of cystic fibrosis lung disease. Proteomics 2006;6(7):2314-2325.

23. Schuliga M. NF-kappaB Signaling in Chronic Inflammatory Airway Disease. Biomolecules 2015;5(3):1266-1283.

24. Chung KF. p38 mitogen-activated protein kinase pathways in asthma and COPD. Chest 2011;139(6):1470-1479.

25. Cho HY, Kleeberger SR. Noblesse oblige: NRF2 functions in the airways. Am J Respir Cell Mol Biol 2014;50(5):844-847.

26. Rangasamy T, Guo J, Mitzner WA, Roman J, Singh A, Fryer AD, et al. Disruption of Nrf2 enhances susceptibility to severe airway inflammation and asthma in mice. J Exp Med 2005;202(1):47-59.

27. Lunardi F, Villano G, Perissinotto E, Agostini C, Rea F, Gnoato M, et al. Overexpression of SERPIN B3 promotes epithelial proliferation and lung fibrosis in mice. Lab Invest 2011;91(6):945-954.

28. Ghafouri B, Irander K, Lindbom J, Tagesson C, Lindahl M. Comparative proteomics of nasal fluid in seasonal allergic rhinitis. J Proteome Res 2006;5(2):330-338.

29. Negrete-Garcia MC, Jimenez-Torres CY, Alvarado-Vasquez N, Montes-Vizuet AR, Velazquez-Rodriguez JR, Jimenez-Martinez MC, et al. Galectin-10 is released in the nasal lavage fluid of patients with aspirin-sensitive respiratory disease. ScientificWorldJournal 2012;2012:474020.

30. Kubach J, Lutter P, Bopp T, Stoll S, Becker C, Huter E, et al. Human CD4+CD25+ regulatory T cells: proteome analysis identifies galectin-10 as a novel marker essential for their anergy and suppressive function. Blood 2007;110(5):15501558.

31. Acharya KR, Ackerman SJ. Eosinophil granule proteins: form and function. J Biol Chem 2014;289(25):1740617415.

32. Cantin AM, North SL, Hubbard RC, Crystal RG. Normal alveolar epithelial lining fluid contains high levels of glutathione. J Appl Physiol (1985) 1987;63(1):152-157.

33. Fitzpatrick AM, Jones DP, Brown LA. Glutathione redox control of asthma: from molecular mechanisms to therapeutic opportunities. Antioxid Redox Signal 2012;17(2):375-408.

34. Grek CL, Zhang J, Manevich Y, Townsend DM, Tew KD. Causes and consequences of cysteine Sglutathionylation. J Biol Chem 2013;288(37):26497-26504.

35. Higgins LG, Hayes JD. Mechanisms of induction of cytosolic and microsomal glutathione transferase (GST) genes by xenobiotics and pro-inflammatory agents. Drug Metab Rev 2011;43(2):92-137.

36. Lee TH, Song HJ, Park CS. Role of inflammasome activation in development and exacerbation of asthma. Asia Pac Allergy 2014;4(4):187-196.

37. Zhao J, Endoh I, Hsu K, Tedla N, Endoh Y, Geczy CL. S100A8 modulates mast cell function and suppresses eosinophil migration in acute asthma. Antioxid Redox Signal 2011;14(9):1589-1600.

38. Lecocq R, Lamy F, Erneux C, Dumont JE. Rapid purification and identification of calcyphosine, a Ca(2+)-binding protein phosphorylated by protein kinase A. Biochem J 1995;306 ( Pt 1):147-151.

39. Magagnotti C, Matassa PG, Bachi A, Vendettuoli V, Fermo I, Colnaghi MR, et al. Calcium signaling-related proteins are associated with broncho-pulmonary dysplasia progression. J Proteomics 2013;94:401-412.

40. Chung YW, Oh HY, Kim JY, Kim JH, Kim IY. Allergen-induced proteolytic cleavage of annexin-1 and activation of cytosolic phospholipase A2 in the lungs of a mouse model of asthma. Proteomics 2004;4(11):3328-3334.

41. Ng FS, Wong KY, Guan SP, Mustafa FB, Kajiji TS, Bist P, et al. Annexin-1-deficient mice exhibit spontaneous airway hyperresponsiveness and exacerbated allergen-specific antibody responses in a mouse model of asthma. Clin Exp Allergy 2011;41(12):1793-1803.

42. Schuliga M, Langenbach S, Xia YC, Qin C, Mok JS, Harris T, et al. Plasminogen-stimulated inflammatory cytokine production by airway smooth muscle cells is regulated by annexin A2. Am J Respir Cell Mol Biol 2013;49(5):751-758. 
Table 1 Characteristics of 82 participants. Continuous variables were expressed as means ( \pm standard deviation) or median (interquartile range) depending on their distribution and categorical values as percentages. Logaritmic transformation was used to attain normal distribution of continuous variables. The differences between the groups were analysed using the ANOVA, Kruskal-Wallis test (when normal distribution was not attained after logarithmic transformation) or Chi-square test.

\begin{tabular}{|c|c|c|c|c|c|}
\hline & $\begin{array}{c}\text { Healthy } \\
\text { controls ( } n=27)\end{array}$ & $\begin{array}{l}\text { protein allergen } \\
\qquad(n=29)\end{array}$ & $\begin{array}{l}\text { Asthma related to } \\
\text { isocyanate }(n=12)\end{array}$ & welding ( $n=14)$ & $\mathbf{p}$ \\
\hline Age, mean (SD) & $43.2(1.9)$ & $42.7(10.3)$ & $41.0(10.9)$ & $43.4(9.9)$ & 0.880 \\
\hline Sex, male, n (\%) & $27(100.0)$ & $10(34.5)$ & $9(75.0)$ & $12(85.7)$ & $<0.001$ \\
\hline $\begin{array}{l}\text { Duration of work exposure, years, } \\
\text { median }\left(Q_{1}-Q_{3}\right)^{\#}\end{array}$ & NA & $\begin{array}{c}9.0 \\
(5.0-27.0)\end{array}$ & $\begin{array}{c}4.0 \\
(2.3-9.5)\end{array}$ & $\begin{array}{c}15.5 \\
(8.8-25.3)\end{array}$ & 0.014 \\
\hline $\begin{array}{l}\text { Duration of asthma symptoms, years, } \\
\text { median }\left(Q_{1}-Q_{3}\right)^{\natural}\end{array}$ & NA & $2.0(2.0-3.5)$ & $1.0(0.6-2.0)$ & $2.0(1.8-9.0)$ & 0.006 \\
\hline VAS rhinitis, mm, median $\left(Q_{1}-Q_{3}\right)^{\#}$ & $\begin{array}{c}12.0 \\
(3.0-25.0)\end{array}$ & $\begin{array}{c}30.0 \\
(7.5-54.5)\end{array}$ & $\begin{array}{c}30.0 \\
(2.0-50.0)\end{array}$ & $\begin{array}{c}10.0 \\
(2.5-45.5)\end{array}$ & 0.123 \\
\hline $\begin{array}{l}\text { VAS nasal congestion, mm, median }\left(Q_{1-}\right. \\
\left.Q_{3}\right)^{\#}\end{array}$ & $\begin{array}{c}12.0 \\
(0.0-22.5)\end{array}$ & $\begin{array}{c}40.0 \\
(14.0-57.3)\end{array}$ & $\begin{array}{c}50.0 \\
(9.0-80.0)\end{array}$ & $\begin{array}{c}30.0 \\
(8.5-71.5)\end{array}$ & 0.003 \\
\hline VAS nasal itching, mm , median $\left(Q_{1}-Q_{3}\right)^{\#}$ & $\begin{array}{c}1.0 \\
(0.0-11.5)\end{array}$ & $\begin{array}{c}20.5 \\
(3.3-38.0)\end{array}$ & $\begin{array}{c}50.0 \\
(2.0-80.0)\end{array}$ & $\begin{array}{c}14.0 \\
(2.5-45.0)\end{array}$ & 0.001 \\
\hline $\begin{array}{l}\text { Nasal steroid during } 4 \text { weeks, } \\
\text { n (\%) }\end{array}$ & $0(0.0)$ & $6(20.7)$ & $2(16.7)$ & $4(28.6)$ & 0.053 \\
\hline Inhaled steroid during 4 weeks, n (\%) & $0.0(0.0)$ & $17(58.6)$ & $7(58.3)$ & $14(100.0)$ & $<0.001$ \\
\hline $\begin{array}{l}\geq 1 \text { SPT positive to common } \\
\text { environmental allergen* }\end{array}$ & $8(29.6)$ & $22(81.5)$ & $5(41.7)$ & $6(42.9)$ & $<0.001$ \\
\hline $\begin{array}{l}\text { Positive SPT to exposed occupational } \\
\text { allergen, } n(\%)^{*}\end{array}$ & NA & $26(96.3)$ & $0(0.0)$ & $0(0.0)$ & $<0.001$ \\
\hline Total IgE, kU/I, median $\left(Q_{1}-Q_{3}\right)^{d}$ & $\begin{array}{c}34.0 \\
(13.0-73.0)\end{array}$ & $\begin{array}{c}187 \\
(51.5-309.5)\end{array}$ & $\begin{array}{c}46.0 \\
(26.3-70.0)\end{array}$ & $\begin{array}{c}61.5 \\
(29.3-132.5)\end{array}$ & $<0.001$ \\
\hline Blood eosinophils $10^{6} / \mathrm{I}$, mean (SD) & $129.3(65.3)$ & $206.6(155.0)$ & $148.3(147.4)$ & $182.5(130.5)$ & 0.137 \\
\hline FVC\% predicted, mean (SD) & $96.9(10.2)$ & $99.4(10.9)$ & $97.9(12.4)$ & $95.7(8.8)$ & 0.706 \\
\hline $\mathrm{FEV}_{1} \%$ predicted, mean (SD) & $95.8(12.7)$ & $91.0(10.8)$ & $92.9(7.3)$ & $88.9(11.5)$ & 0.239 \\
\hline FeNO, ppb, median $\left(Q_{1}-Q_{3}\right)^{\natural}$ & $\begin{array}{c}13.2 \\
(11.9-16.9)\end{array}$ & $\begin{array}{c}23.2 \\
(12.8-37.9)\end{array}$ & $\begin{array}{c}17.0 \\
(10.4-26.9)\end{array}$ & $\begin{array}{c}23.0 \\
(13.7-32.9)\end{array}$ & 0.004 \\
\hline nNO, ppb, mean (SD) & $836.2(272.7)$ & $929.5(351.1)$ & $760.6(233.8)$ & $896.1(339.8)$ & 0.400 \\
\hline $\begin{array}{l}\text { Sputum eosinophil \%, median }\left(Q_{1}-Q_{3}\right) \text {, } \\
n=57^{\#}\end{array}$ & $0.0(0.0-0.25)$ & $1.0(0.0-4.0)$ & $1.0(0.0-1.5)$ & $0.5(0.0-1.0)$ & 0.044 \\
\hline Nasal eosinophil \%, median $\left(Q_{1}-Q_{3}\right)^{\#}$ & $0.0(0.0-0.0)$ & $0.0(0.0-1.0)$ & $1.0(0.0-1.0)$ & $0.0(0.0-0.0)$ & 0.009 \\
\hline
\end{tabular}


\# Kruskal-Wallis test was used; Logaritmic transformation was used; *two participants with negative control wheal $\geq 2 \mathrm{~mm}$ were excluded from analysis; VAS, Visual analogue scale of nasal symptoms within a week; SPT, skin prick test; IgE, Immunoglobulin E; FVC, forced vital capacity; FEV Forced expiratory volume in one second; FeNO, exhaled nitric oxide; nNO, nasal nitric oxide. 
Table 2 Relationships between differently abundant proteins in study groups. Average ratios $(\geq|1.5|$ fold change in abundance) of statistically significant (Student's T-test p-value $\leq 0.05$ ) up-and down-regulated nasal mucosa proteins are presented for the protein allergen, isocyanate and welding exposed asthma groups in comparison to the control group.

\begin{tabular}{|c|c|c|c|c|c|}
\hline Protein Name & UniProt AC & Gene ID & $\begin{array}{l}\text { Protein } \\
\text { allergen } \\
\text { vs Control } \\
\text { Av. ratio }\end{array}$ & $\begin{array}{c}\text { Isocyanate } \\
\text { vs Control } \\
\text { Av. ratio }\end{array}$ & $\begin{array}{c}\text { Welding vs } \\
\text { Control } \\
\text { Av. ratio }\end{array}$ \\
\hline Alpha-2-macroglobulin (A2MG) & P01023 & $\mathrm{A} 2 \mathrm{M}$ & 1,83 & & \\
\hline Complement C3 (CO3) & P01024 & C3 & 1,82 & & \\
\hline Complement factor B (CFAB) & P00751 & CFB & 1,88 & 1,88 & \\
\hline Alpha-actinin-4 (ACTN4) & 043707 & ACTN4 & & $-1,77$ & $-1,95$ \\
\hline Serum albumin (ALBU) & P02768 & ALB & 3,17 & 2,81 & 2,36 \\
\hline $\begin{array}{l}\text { Polymeric immunoglobulin receptor } \\
\text { (PIGR) }\end{array}$ & P01833 & PIGR & 1,85 & & \\
\hline $\begin{array}{l}\text { Protein-glutamine gamma- } \\
\text { glutamyltransferase (TGM3) }\end{array}$ & Q08188 & TGM3 & 2 & & \\
\hline Lactotransferrin (TRFL) & P02788 & TRFL & 5,43 & 4,95 & 2,87 \\
\hline Ig mu chain C region (IGHM) & P01871 & IGHM & 1,89 & & \\
\hline Serotransferrin (TRFE) & P02787 & TF & 1,75 & & \\
\hline $\begin{array}{l}\text { Heat shock cognate } 71 \text { kDa protein } \\
\text { (HSP7C) }\end{array}$ & P11142 & HSPA8 & & & $-2,49$ \\
\hline Protein disulfide-isomerase (PDIA1) & P07237 & $\mathrm{P} 4 \mathrm{HB}$ & & 1,67 & \\
\hline Histidine ammonia-lyase (HUTH) & P42357 & $\mathrm{HAL}$ & & 1,74 & \\
\hline $\begin{array}{l}\text { Glucose-6-phosphatate isomerase } \\
\text { (G6PI) }\end{array}$ & P06744 & GPI & & & 2,09 \\
\hline $\begin{array}{l}\text { Pyruvate kinase isozymes M1/M2 } \\
\text { (KPYM) }\end{array}$ & P14618 & PKM & & & 2,45 \\
\hline Ig alpha-1 chain C region (IGHA1) & P01876 & IGHA1 & 2,04 & & \\
\hline Alpha-1-antitrypsin (A1AT) & P01009 & SERPINA1 & 2,15 & & \\
\hline $\begin{array}{l}\text { Histidine--tRNA ligase; cytoplasmic } \\
\text { (SYHC) }\end{array}$ & P12081 & HARS & $-1,57$ & & \\
\hline $\begin{array}{l}\text { Tryptophan-tRNA ligase; cytoplasmic } \\
\text { (SYWC) }\end{array}$ & P23381 & WARS & $-1,67$ & & \\
\hline Aldehyde dehydrogenase (AL3A1) & P30838 & ALDH3A1 & $-2,76$ & $-3,4$ & $-2,19$ \\
\hline Selenium-binding protein 1 (SBP1) & Q13228 & SELENBP1 & $-2,05$ & $-1,58$ & \\
\hline Glutathione synthetase (GSHB) & P48637 & GSS & $-2,08$ & & \\
\hline Retinal dehydrogenase 1 (AL1A1) & P00352 & ALDH1A1 & $-2,25$ & & \\
\hline $\begin{array}{l}\text { Rab GDP dissociation inhibitor beta } \\
\text { (GDIB) }\end{array}$ & P50395 & GDI2 & $-2,51$ & -2 & $-1,71$ \\
\hline $\begin{array}{l}\text { Glyceraldehyde-3-phosphate } \\
\text { dehydrogenase (G3P) }\end{array}$ & P04406 & GAPDH & $-1,51$ & $-1,55$ & \\
\hline 6-phosphogluconate dehydrogenase & & & & & \\
\hline$(6 P G D)$ & P52209 & PGD & & 2,32 & 2 \\
\hline Catalase (CATA) & P04040 & CAT & 1,77 & 2,87 & \\
\hline Zinc-alpha-2-glycoprotein (ZA2G) & P25311 & AZGP1 & & 1,63 & \\
\hline Serpin B3 (SPB3) & P29508 & SERPINB3 & $-2,02$ & $-1,92$ & $-1,72$ \\
\hline $\begin{array}{l}26 \mathrm{~S} \text { proteasome non-ATPase } \\
\text { regulatory subunit } 11 \text { (PSD11) }\end{array}$ & 000231 & PSMD11 & $-1,58$ & & \\
\hline Haptoglobin (HPT) & P00738 & $\mathrm{HP}$ & 2,02 & & \\
\hline $\begin{array}{l}\text { Isocitrate deheydrogenase [NADP]; } \\
\text { cytoplasmic (IDHC) }\end{array}$ & 075874 & IDH1 & $-2,74$ & & \\
\hline Arginosuccinate synthase (ASSY) & P00966 & ASS1 & $-2,79$ & & \\
\hline Creatine kinase B-type (KCRB) & P12277 & CKB & 1,71 & & \\
\hline Fructose-bisphosphate aldolase $A$ & & & & & \\
\hline$(A L D O A)$ & P04075 & ALDOA & $-2,53$ & & \\
\hline Leukocyte elastase inhibitor (ILEU) & P30740 & SERPINB1 & $-1,56$ & & \\
\hline GDP-L-fucose synthase (FLC) & Q13630 & TSTA3 & $-1,97$ & & \\
\hline $\begin{array}{l}\text { Plasminogen activator inhibitor } 2 \\
\text { (PAI2) }\end{array}$ & P05120 & SERPINB2 & $-1,8$ & & \\
\hline Alcohol dehydrogenase [NADP(+)] & P14550 & AK1A1 & $-3,06$ & & \\
\hline
\end{tabular}




\begin{tabular}{|c|c|c|c|c|c|}
\hline Annexin A1 (ANXA1) & P04083 & ANXA1 & $-3,78$ & $-5,05$ & \\
\hline Annexin A2 (ANXA2) & P07355 & ANXA2 & $-4,59$ & $-5,75$ & \\
\hline Annexin A3 (ANXA3) & P12429 & ANXA3 & $-1,9$ & & \\
\hline Annexin A5 (ANXA5) & P08758 & ANXA5 & $-2,59$ & & \\
\hline S-formylglutathione hydrolase (ESTD) & P10768 & ESD & $-2,18$ & & \\
\hline Tropomyosin alpha-1 chain (TPM1) & P09493 & TMP1 & -19 & & \\
\hline Tropomyosin alpha-4 chain (TPM4) & P67936 & TMP4 & כ,1- & & \\
\hline Actin; cytoplasmic 1 (ACTB) & P60709 & АСТВ & $-1,68$ & & \\
\hline \multicolumn{6}{|l|}{ Chloride intracellular channel protein1 } \\
\hline$(\mathrm{CLIC} 1)$ & 000299 & CLIC1 & $-1,8$ & & $-1,56$ \\
\hline 14-3-3 protein sigma (1433S) & P31947 & SFN & $-1,88$ & & \\
\hline 14-3-3 protein zeta/delta (1433Z) & P63104 & YWHAZ & $-2,14$ & $-1,58$ & $-1,85$ \\
\hline 14-3-3 protein epsilon (1433E) & P62258 & YWHAE & $-2,63$ & $-2,27$ & $-1,9$ \\
\hline Serum amyloid P-component (SAMP) & P02743 & APCS & 1,75 & 2,01 & \\
\hline \multicolumn{6}{|l|}{ Proteasome subunit alpha type-5 } \\
\hline (PSA5) & P28066 & PSMA5 & $-1,96$ & & \\
\hline Kallikrein-7 (KLK7) & P49862 & KLK7 & $-2,75$ & $-2,34$ & $-1,89$ \\
\hline Glutathione S-transferase P (GSTP1) & P09211 & GSTP1 & $-2,6$ & $-1,93$ & \\
\hline \multicolumn{6}{|l|}{ Complement C1q subcomponent } \\
\hline subunit C (C1QC) & P02747 & C1QC & & 1,6 & \\
\hline Heat shock protein beta-1 (HSPB1) & P04792 & HSPB1 & 1,75 & 1,85 & \\
\hline \multicolumn{6}{|l|}{ BPI fold-containing family A member 1} \\
\hline$(\mathrm{BPIA} 1)$ & Q9NP55 & BPIFA1 & & $-1,96$ & \\
\hline \multicolumn{6}{|l|}{ Translationally-controlled tumour } \\
\hline Peroxiredoxin-2 (PRDX2) & P32119 & PRDX2 & $-2,5$ & & \\
\hline Peroxiredoxin-1 (PRDX1) & Q06830 & PRDX1 & $-3,6$ & & \\
\hline \multicolumn{6}{|l|}{ Phosphatidylethanolamine-binding } \\
\hline \multicolumn{6}{|l|}{ Adenine phosphoribosyltransferase } \\
\hline (APT) & P07741 & APRT & $-3,11$ & & \\
\hline Calcyphosin (CAYP1) & Q13938 & CAPS & $-4,76$ & $-5,15$ & \\
\hline \multicolumn{6}{|l|}{ Nucleoside diphosphatate kinase A } \\
\hline$(\mathrm{NDKA})$ & P15531 & NME1 & & $-1,58$ & \\
\hline Thioredoxin (THIO) & P10599 & THIO & & $-2,16$ & \\
\hline Superoxide dismutase [Cu-Zn] (SODC) & P00441 & SOD1 & $-1,98$ & $-2,21$ & \\
\hline Cofilin-1 (COF1) & P23528 & CFL1 & $-2,13$ & $-2,13$ & \\
\hline \multicolumn{6}{|l|}{ Nucleoside diphosphatate kinase B } \\
\hline (NDKB) & P22392 & NME2 & $-2,26$ & & \\
\hline Prolactin-inducible protein (PIP) & P12273 & PIP & 2,22 & & \\
\hline Peroxiredoxin 5 (PRDX5) & P30044 & PRDX5 & $-2,85$ & & \\
\hline \multicolumn{6}{|l|}{ Peptidyl-prolyl cis-trans isomerase A } \\
\hline$(\mathrm{PPIA})$ & P62937 & PPIA & $-2,86$ & & \\
\hline \multicolumn{6}{|l|}{ Fatty acid binding protein, epidermal } \\
\hline$(\mathrm{FABP} 5)$ & Q01469 & FABP5 & & & 2,69 \\
\hline Galectin 10 (LEG10) & Q05315 & $\mathrm{CLC}$ & 4,04 & & \\
\hline Haemoglobin subunit beta (HBB) & P68871 & HBB & & & $-2,27$ \\
\hline Protein S100-A9 (S10A9) & P06702 & S100A9 & 2,2 & 7,11 & 8,71 \\
\hline Protein S100-A8 (S10A8) & P05109 & S100A8 & 2,43 & & \\
\hline
\end{tabular}

Table 3 Pathways and diseases linked to the observed proteomic changes in the nasal mucosa after exposure to protein allergen, isocyanate and welding fume.

Canonical pathways

\begin{tabular}{l|l|l} 
Protein allergen & Isocyanate & Welding \\
\hline Acute Phase Response Signalling & Superoxide Radicals Degradation & Glycolysis I
\end{tabular}


NRF2-mediated Oxidative Stress Response

Tryptophan Degradation X

LXR/RXR Activation

Ethanol Degradation IV
NRF2-mediated Oxidative Stress Response

Ethanol Degradation IV

Aryl Hydrocarbon Receptor

Signalling

Complement System
Cell Cycle: DNA Damage Checkpoint Regulation

Myc Mediated Apoptosis Signalling ERK5 Signalling

HIPPO signalling

Diseases and Disorders

\begin{tabular}{l|l|l} 
Protein allergen & Isocyanate & Welding \\
\hline Inflammatory Response & Inflammatory Response & $\begin{array}{l}\text { Dermatological Diseases and } \\
\text { Conditions }\end{array}$ \\
$\begin{array}{l}\text { Immunological Disease } \\
\text { Dermatological Diseases and Conditions }\end{array}$ & $\begin{array}{l}\text { Dermatological Diseases and } \\
\text { Conditions }\end{array}$ & Immunological Disease \\
Haematological Disease & Neurological Disease & Neurological Disease \\
Inflammatory Disease & Skeletal and Muscular Disorders & Psychological Disorders \\
\end{tabular}

The top five canonical pathways and disease-associated functions from the Ingenuity Pathway Analysis of the affected protein levels in protein allergen, isocyanate and welding challenged groups compared to the control group. The $p$-values of likelihoods for the protein list of each study group were calculated using the Fisher Exact test. The top five p-values were for protein allergens from E-21 to E-08, for isocyanate from E-11 to E-07 and for the welding group with the shortest identified protein list from E-11 to E-05. 


\section{Figure legends}

Figure 1 Study flow chart. HDI, Hexamethylene diisocyanate; MDI, Methylene diphenyl diisocyanate.

Figure $\mathbf{2}$ Clustering analyses of the differentially abundant proteins between study groups. A heat map of hierarchical clustering (A), on which nasal epithelial proteins with decreased abundance are marked in green and those with increased abundance in red; and Principal Component Analysis (B-C), in which spheres correspond to a study group (Fig. 2B) or to an identified gel spot (Fig. 2C). In the Fig. $2 \mathrm{C}$ the further apart from the origo a spot is, the clearer the separation between the groups, and the more suitable the finding would be as a biomarker. All figures indicate differences between the protein allergen (Protein) and isocyanate (Isocyanate) groups and the healthy controls (Control), whereas the welding group (Welding) shows the least up- or down-regulation to healthy persons. Immunoblot analysed gel spots are highlighted in Fig. 2C.

Figure 3 Comparison of protein abundance by Western blotting. 2D-DIGE gel spot intensities for Glutathione S-transferase 1 (GSTP1, mean of several spots/gel), Galectin 10 (LEG10, one gel spot), Protein S100-A9 (S10A9, mean of several spots/gel) and Calcyphosin (CAYP1, one gel spot) of the 32 nasal brush samples (NBS) are on the left. The corresponding protein levels in the Western blot analysis for 82 NBS are on the right. Bars indicate means. Logaritmic transformation was used to attain normal distribution of the variables. The differences between the groups were analysed using the Anova and Fisher's LSD test for post hoc comparisons. Control = healthy persons, Protein= protein allergens group; Isocyanate= isocyanate group; Welding= welding group. 
Figure 1.

82 Nonsmoking subjects investigated 2009-2012

Patients examined for work-related asthma divided by the type of exposure

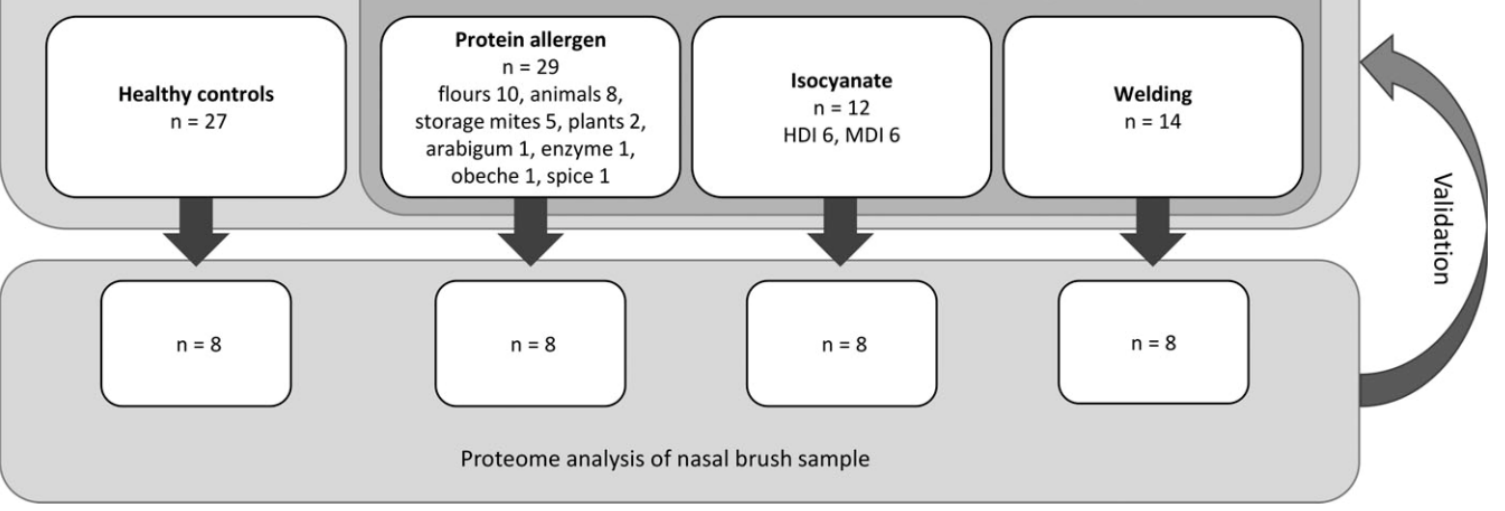


Figure 2.

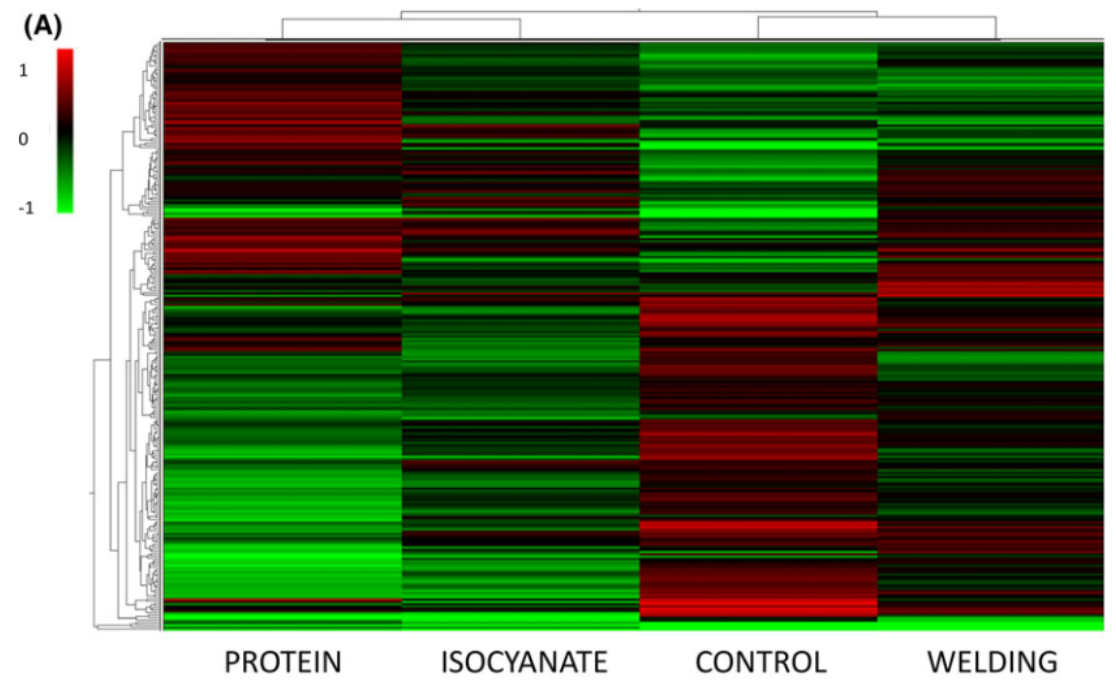

(B)

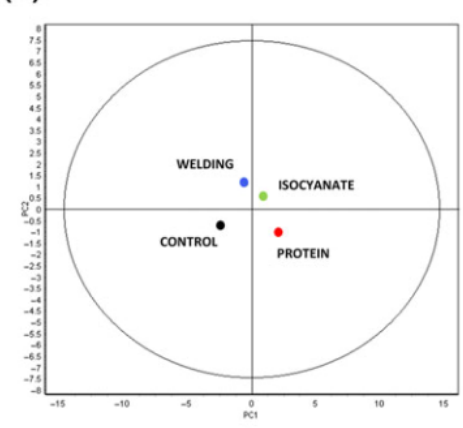

(C)

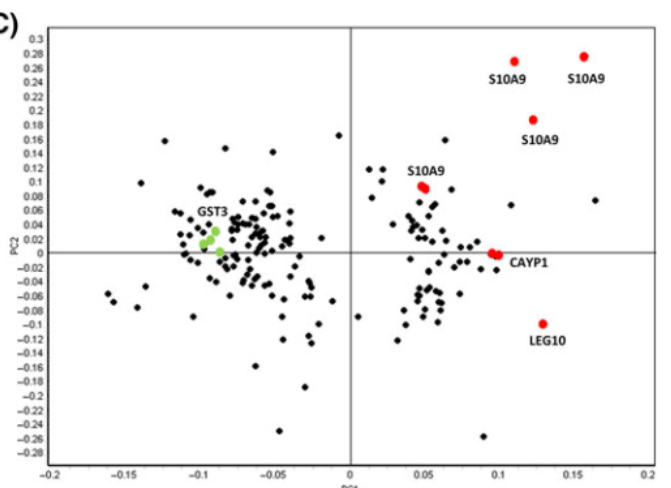


Figure 3.

\section{Supplementary data}

\section{Supplementary material 1 \\ Methods}

\section{Skin prick tests and IgE measurements}

The skin prick test (SPT) panel for common environmental allergens included a negative control, a positive control (histamine), and 11 standardized environmental antigens (ALK-Abello, Hørsholm, Denmark). Occupational protein allergens were tested with commercial extracts, as is, or as an in-house extract in potassium phosphate, depending on the agent. Isocyanates were conjugated with human serum albumin (1), and metals $\left(\mathrm{CoCl}_{2}, \mathrm{NiSO}_{4}, \mathrm{~K}_{2} \mathrm{CrO}_{4}, \mathrm{CrCl}_{2}\right)$ were diluted in aqua. The results were regarded as positive if the mean wheal diameter was $\geq 3 \mathrm{~mm}$, and the negative control wheal was $<2 \mathrm{~mm}$. Serum total and specific (protein allergens and isocyanates) IgE were measured using the Phadia UniCAP System (Phadia, Uppsala, Sweden). A specific IgE of $<0.35 \mathrm{kU} / \mathrm{l}$ was considered normal.

Lung function, exhaled and nasal nitric oxide

Flow-volume spirometry was performed using a standard spirometer (Spirostar USB Medikro, Finland), and the predicted values of the Finnish population. Nonspecific airway hyperresponsiveness was measured using the histamine challenge (2). Exhaled (FeNO) and nasal ( $\mathrm{nNO}$ ) nitric oxide were measured using an online chemiluminescence analyser (NIOX, Aerocrine $A B$, Solna, Sweden) in compliance with recommendations (3).

\section{Controlled exposure to occupational agent}

The WRA patients were exposed to the relevant occupational agent for 15-30 minutes approximately $24 \mathrm{~h}$ before sample collection, by mimicking work tasks in a $6 \mathrm{~m}^{3}$ challenge chamber or by nebulizing allergen extracts (animal dander, storage mites), in-house solutions (Methylene diphenyl diisocyanate) or occupational agents (Hexamethylene diisocyanate) (4).

\section{Nasal brush and induced sputum samples}

The NBS was taken from the nasal cavity's middle meatus. The brush was dipped into $5 \mathrm{~mL}$ of cold PBS, mixed gently and centrifuged at $500 \mathrm{~g}$. Supernatant was filtered through a $0.45 \mu \mathrm{m}$ membrane, divided into aliquots and frozen to $-70 \circ \mathrm{C}$ for further use. Sputum was induced with hypertonic saline, in accordance with the guidelines (5). The number of eosinophils /200 cells were counted in the sputum and the NBS smear samples.

1 Helaskoski E, Suojalehto H, Kuuliala O, Aalto-Korte K. Prick testing with chemicals in the diagnosis of occupational contact urticaria and respiratory diseases. Contact Dermatitis 2015: 72: 20-32. Sovijarvi A R, Malmberg L P, Reinikainen K, Rytila P, Poppius H. A rapid dosimetric method with controlled tidal breathing for histamine challenge. Repeatability and distribution of bronchial reactivity in a clinical material. Chest 1993: 104: 164-70. Ats/Ers. ATS/ERS recommendations for standardized procedures for the online and offline measurement of exhaled lower respiratory nitric oxide and nasal nitric oxide, 2005. Am J Respir Crit Care Med 2005: 171: $912-$ 30. Vandenplas O, Suojalehto H, Aasen T B, Baur X, Burge P S, De Blay F, Fishwick D, Hoyle J, Maestrelli P, Munoz X, Moscato G, Sastre J, Sigsgaard T, Suuronen K, Walusiak-Skorupa J, Cullinan P. Specific inhalation challenge in the diagnosis of occupational asthma: consensus statement. Eur Respir J 2014: 43: 1573-87. Djukanovic R, Sterk P J, Fahy J V, Hargreave F E. Standardised methodology of sputum induction and processing. Eur Respir J Suppl 2002: 37: 1s-2s. 
Table S1. Characteristics of 32 participants whose nasal brush samples were included in proteomic analysis. Continuous variables were expressed as means ( \pm standard deviation) or median (interquartile range) depending on their distribution and categorical values as percentages. Logaritmic transformation was used to attain normal distribution of continuous variables. The differences between the groups were analysed using the ANOVA, Kruskal-Wallis test (when normal distribution was not attained after logarithmic transformation) or Chi-square test.

\begin{tabular}{|c|c|c|c|c|c|}
\hline & $\begin{array}{c}\text { Healthy } \\
\text { controls }(n=8)\end{array}$ & $\begin{array}{l}\text { protein allergen } \\
\qquad(n=8)\end{array}$ & $\begin{array}{l}\text { Asthma related to } \\
\text { isocyanate }(n=8)\end{array}$ & welding $(n=8)$ & $\mathbf{p}$ \\
\hline Age & $43.8(2.1)$ & $35.6(12.3)$ & $41.7(11.4)$ & $43.3(10.4)$ & 0.349 \\
\hline Sex, male, n (\%) & $8(100.0)$ & $1(12.5)$ & $6(75.0)$ & $6(75.0)$ & 0.002 \\
\hline $\begin{array}{l}\text { Duration of work exposure, years, } \\
\text { median }\left(Q_{1}-Q_{3}\right)^{\#}\end{array}$ & NA & $7.5(5.3-25.5)$ & $6.5(2.3-13.8)$ & $21.5(6.3-25.8)$ & 0.265 \\
\hline $\begin{array}{l}\text { Duration of asthma symptoms, years, } \\
\text { median }\left(Q_{1}-Q_{3}\right)^{\not 2}\end{array}$ & NA & $3.0(2.3-4.0)$ & $1.0(0.7-2.8)$ & $3.5(1.3-9.8)$ & 0.032 \\
\hline VAS rhinitis, mm, median $\left(\mathrm{Q}_{1}-\mathrm{Q}_{3}\right)^{\#}$ & $10.5(0.0-16.3)$ & $57.5(11.8-66.8)$ & $20.0(0.0-50.0)$ & $7.5(0.0-38.5)$ & 0.083 \\
\hline $\begin{array}{l}\text { VAS nasal congestion, } \mathrm{mm} \text {, median }\left(\mathrm{Q}_{1^{-}}\right. \\
\left.\mathrm{Q}_{3}\right)^{\#}\end{array}$ & $5.0(0.0-20.5)$ & $49.5(30.3-71.3)$ & $80.0(30.0-84.0)$ & $14.5(2.3-45.5)$ & 0.021 \\
\hline VAS nasal itching, mm, median $\left(\mathrm{Q}_{1}-\mathrm{Q}_{3}\right)^{\#}$ & $0.0(0.0-0.0)$ & $45.0(16.8-59.8)$ & $60.0(0.0-80.0)$ & $4.5(0.3-16.3)$ & 0.002 \\
\hline $\begin{array}{l}\text { Nasal steroid during } 4 \text { weeks, } \\
\mathrm{n}(\%)\end{array}$ & $0(0.0)$ & $1(12.5)$ & $1(12.5)$ & $2(25.0)$ & 0.515 \\
\hline Inhaled steroid during 4 weeks, n (\%) & $0(0.0)$ & $3(37.5)$ & $5(62.5)$ & $8(100.0)$ & 0.001 \\
\hline $\begin{array}{l}\geq 1 \text { positive SPT to common } \\
\text { environmental allergen, } n(\%)\end{array}$ & $0(0.0)$ & $7(87.5)$ & $3(37.5)$ & $4(50.0)$ & 0.005 \\
\hline $\begin{array}{l}\text { Positive SPT to occupational allergen, } \\
\mathrm{n}(\%)\end{array}$ & NA & $8(100.0)$ & $0(0.0)$ & $0(0.0)$ & $<0.001$ \\
\hline Total IgE, kU/l, median $\left(\mathrm{Q}_{1}-\mathrm{Q}_{3}\right)^{\not}$ & $\begin{array}{c}16.5 \\
(8.8-23.3)\end{array}$ & $\begin{array}{c}143.0 \\
(42.8-301.8)\end{array}$ & $\begin{array}{c}40.0 \\
(17.5-63.5)\end{array}$ & $\begin{array}{c}95.5 \\
(32.8-203.0)\end{array}$ & 0.007 \\
\hline Blood eosinophils $10^{6} / \mathrm{l}$, mean (SD) & $128.8(86.8)$ & $255.0(166.2)$ & $183.8(172.5)$ & 207.5 (129.9) & 0.374 \\
\hline FVC \% predicted, mean (SD) & $98.6(8.1)$ & $99.9(10.1)$ & $97.3(14.1)$ & $94.9(10.7)$ & 0.821 \\
\hline FEV1 \% predicted, mean (SD) & $97.9(9.8)$ & $92.6(9.5)$ & $92.5(8.5)$ & $91.0(12.9)$ & 0.573 \\
\hline FeNO, ppb, median $\left(Q_{1}-Q_{3}\right)^{x}$ & $12.8(11.1-16.9)$ & $32.3(18.5-69.4)$ & $15.8(10.4-25.1)$ & $18.8(10.5-39.9)$ & 0.009 \\
\hline nNO, ppb, mean (SD) & $858.7(263.4)$ & $1006.7(358.1)$ & $694.4(233.6)$ & $927.1(370.0)$ & 0.249 \\
\hline $\begin{array}{l}\text { Sputum eosinophil \%, median }\left(Q_{1}-Q_{3}\right) \text {, } \\
n=20^{\#}\end{array}$ & $0.0(0.0-0.3)$ & $3.0(0.5-6.5)$ & $1.0(0.0-2.0)$ & $0.5(0.0-1.0)$ & 0.080 \\
\hline Nasal eosinophil \%, median $\left(\mathrm{Q}_{1}-\mathrm{Q}_{3}\right)^{\#}$ & $0.0(0.0-0.0)$ & $0.5(0.0-1.75)$ & $1.0(0.0-4.0)$ & $0.0(0.0-0.0)$ & 0.056 \\
\hline
\end{tabular}

\# Kruskal-Wallis test was used; " $L$ Logaritmic transformation was used; VAS, Visual analogue scale of nasal symptoms within a week; SPT, skin prick test; IgE, Immunoglobulin E; FVC, forced vital capacity; FEV 1 , Forced expiratory volume in one second; FeNO, exhaled nitric oxide; nNO, nasal nitric oxide. 
Table S2

Table S2. List of identified proteins from 2D-DIGE analysis of nasal brush samples. Proteins were identified from the picked 228 gel spots by tandem mass spectrometry with subsequent database searches using Proteome Discover software. Student's t-test and the Average (Av.) Ratio (with significance levels of $<0.05$ and AV. Ratio $\geq|1.5|$, respectively) for comparing inhalation challenged protein, isocyanate and welding groups and healthy controls to one another were obtained from Decyder software.

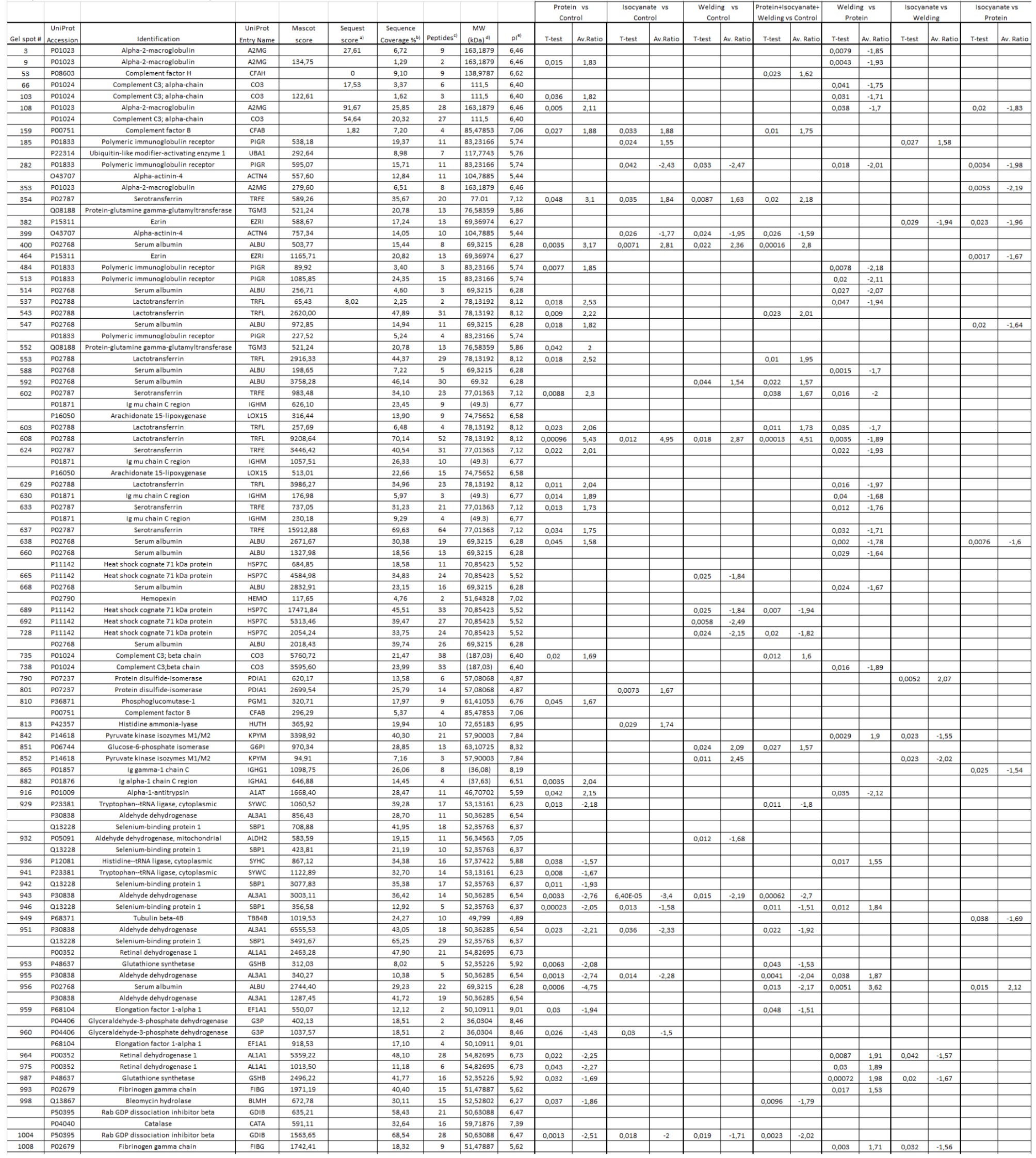




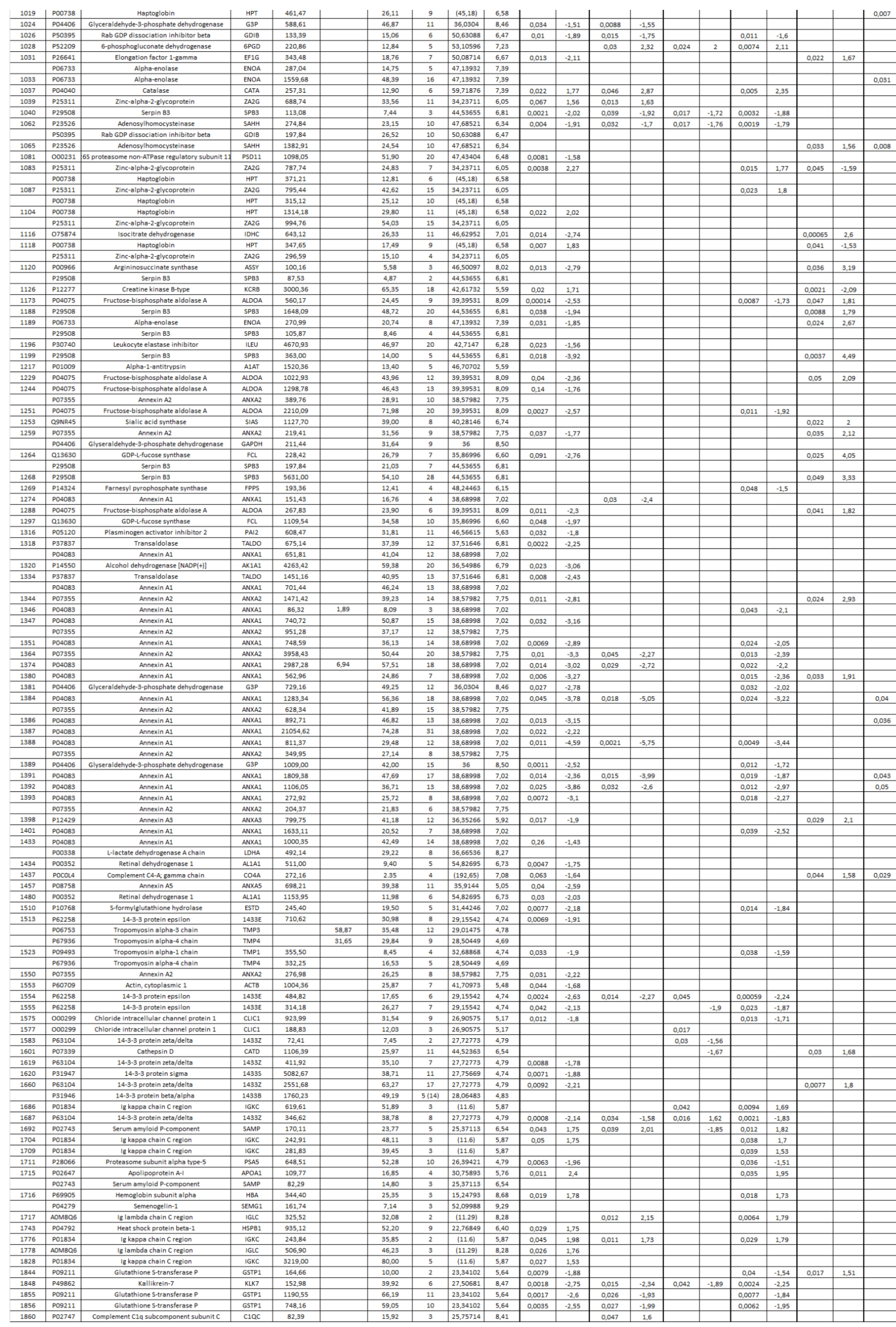




\begin{tabular}{|c|c|c|c|c|c|c|c|c|c|c|c|c|c|c|c|c|c|c|c|c|}
\hline 1865 & P04792 & Heat shock protein beta-1 & HSPB1 & 543,80 & & 29,76 & 5 & 22,76849 & 6,40 & & & 0,037 & 1,85 & & & & & & & \\
\hline 1868 & P09211 & Glutathione S-transferase $P$ & GSTP1 & 1445,67 & & 35,71 & 5 & 23,34102 & 5,64 & 0,016 & $-2,85$ & & & & & 0,031 & $-1,99$ & & & \\
\hline \multirow[t]{2}{*}{1874} & 006830 & Peroxiredoxin-1 & PRDX1 & 108,39 & & 25,63 & 5 & 22,09628 & 8,13 & 0,036 & $-1,97$ & & & & & & & & & \\
\hline & P13693 & Translationally-controlled tumor protein & TCTP & 83,17 & & 15,70 & 2 & 19,58258 & 4,93 & & & & & & & & & & & \\
\hline 1890 & Q9NP55 & BPI fold-containing family A member 1 & BPIA1 & 150,04 & & 21,09 & 4 & 26,69593 & 5,76 & & & 0,034 & $-1,96$ & & & & & & & \\
\hline 1892 & 006830 & Peroxiredoxin-1 & PRDX1 & 468,34 & & 55,78 & 10 & 22,09628 & 8,13 & 0,036 & $-2,21$ & & & & & & & & & \\
\hline 1908 & P13693 & Translationally-controlled tumor protein & TCTP & 123,90 & & 24,42 & 4 & 19,58258 & 4,93 & 0,0022 & $-1,95$ & 0,011 & $-1,9$ & 0,045 & & 0,0011 & $-1,8$ & & & \\
\hline 1914 & Q068830 & $\begin{array}{l}\text { Peroxiredoxin-1 } \\
\end{array}$ & PRDX1 & 1589,03 & & 67,34 & 15 & 22,09628 & 8,13 & 0,025 & $-3,46$ & & & & $-1,59$ & & & & & \\
\hline \multirow{2}{*}{1920} & P32119 & Peroxiredoxin-2 & PRDX2 & 560,07 & & 32,32 & 8 & 21,87824 & 5,97 & 0,0027 & $-2,5$ & & & & & 0,0021 & -2 & & & \\
\hline & P30085 & UMP-CMP kinase & $\mathrm{KCY}$ & 556,65 & & 53,06 & 8 & 22,20828 & 5,57 & & & & & & & & & & & \\
\hline 1933 & Q068830 & Peroxiredoxin-1 & PRDX1 & 3490,46 & & 87,94 & 18 & 22,09628 & 8,13 & & & & & & & & & 0,019 & 3,74 & \\
\hline 1939 & Q068830 & Peroxiredoxin-1 & PRDX1 & 98,63 & & 13,07 & 3 & 22,09628 & 8,13 & 0,024 & $-3,6$ & & & & & 0,04 & $-2,2$ & 0,016 & 2,15 & \\
\hline 1963 & P30086 & Phosphatidylethanolamine-binding protein 1 & PEBP1 & 1586,33 & & 50,27 & 8 & 21,04367 & 7,53 & 0,033 & $-2,18$ & & & & & & & & & \\
\hline 1971 & P07741 & Adenine phosphoribosyltransferase & APT & 364,82 & & 28,33 & 4 & 19,59543 & 6,02 & 0,048 & $-3,11$ & & & & & & & & & \\
\hline 1976 & Q.13938 & Calcyphosin & CAYP1 & 364,21 & & 35,45 & 7 & 20,95428 & 4,89 & & & 0,031 & $-2,09$ & & & 0,045 & $-1,74$ & & & \\
\hline 1978 & Q13938 & Calcyphosin & CAYP1 & 1739,67 & & 51,32 & 13 & 20,95428 & 4,89 & 0,029 & $-4,76$ & 0,029 & $-5,15$ & & & 0,014 & $-3,72$ & & & \\
\hline 1998 & P06702 & Protein $5100-A 9$ & S10A9 & 1155,94 & & 48,25 & 6 & 13,23351 & 6,13 & & & 0,049 & $-2,98$ & & & & & & & \\
\hline & P05109 & Protein S100-A8 & S10AB & 952,00 & & 58,06 & 8 & 10,8 & 6,1 & & & & & & & & & & & \\
\hline 2013 & $\begin{array}{l}P 12273 \\
\end{array}$ & Prolactin-inducible protein & PIP & 506,38 & & 47,95 & 6 & 16,5618 & 8,05 & & & & & & & & & & & 0,014 \\
\hline 2032 & P12273 & Prolactin-inducible protein & PIP & 306,84 & & 66,44 & 10 & 16,5618 & 8,05 & & & 0,017 & $-4,34$ & 0,029 & & & & & & \\
\hline & P30626 & Sorcin & SORCN & 276,07 & & 27,27 & 6 & 21,66236 & 5,59 & & & & & & & & & & & \\
\hline 2036 & P00738 & Haptoglobin & HPT & 177,13 & & 6,16 & 2 & (45.18) & 6,58 & & & & & & $-2,64$ & & & 0,014 & $-2,91$ & \\
\hline 2037 & P00738 & Haptoglobin & HPT & 334,72 & & 6,90 & 4 & $(45.18)$ & 6,58 & & & & & & & & & 0,04 & $-2,03$ & \\
\hline 2043 & P15531 & Nucleoside diphosphate kinase A & NOKA & 1086,01 & & 63,82 & 9 & 17,13767 & 6,19 & & & 0,029 & $-1,58$ & & & & & & & \\
\hline & P00738 & Haptoglobin & HPT & 285,01 & & 7,39 & 6 & (45.18) & 6,58 & & & & & & & & & & & \\
\hline 2052 & P00738 & Haptoglobin & HPT & 259,32 & & 8,37 & 4 & $(45.18)$ & 6,58 & & & & & & & & & 0,027 & $-2,48$ & \\
\hline 2064 & P10599 & Thioredoxin & THIO & 114,96 & & 12,38 & 1 & 11,72974 & 4,92 & & & 0,033 & $-2,16$ & & & & & & & \\
\hline 2076 & P00441 & Superoxide dismutase $[\mathrm{Cu}-\mathrm{Zn}]$ & SODC & 101,62 & & 9,09 & 1 & 15,9259 & 6,13 & & & 0,013 & $-2,63$ & & & 0,012 & $-2,06$ & & & \\
\hline 2078 & P00441 & Superoxide dismutase [Cu-Zn] & sooc & 1869,73 & & 27,92 & 4 & 15,9259 & 6,13 & & & 0,027 & $-2,32$ & & & 0,0053 & $-1,85$ & & & \\
\hline 2080 & P00441 & Superoxide dismutase [Cu-Zn] & SODC & 119,94 & & 9,09 & 1 & 15,9259 & 6,13 & 0,013 & $-1,98$ & 0,0088 & $-2,21$ & & & 0,045 & $-1,72$ & & & \\
\hline 2083 & P23528 & Cofilin-1 & COF1 & 80,03 & & 6,63 & 1 & 18,49066 & 8,09 & & & & & & & 0,014 & $-2,14$ & & & \\
\hline 2085 & P23528 & Cofilin-1 & COF1 & 119,46 & & 18,67 & 2 & 18,49066 & 8,09 & 0,012 & $-2,89$ & & & & & & & & & \\
\hline 2087 & P23528 & Cofilin-1 & COF1 & 329,14 & & 35,54 & 8 & 18,49066 & 8,09 & Hits, E- E-Is: & / Kont & & & & & 0,023 & $-2,34$ & & & \\
\hline 2095 & P37802 & Transgelin-2 & TAGL2 & 371,89 & & 24,62 & 4 & 22,37717 & 8,25 & 0,0038 & $-3,16$ & 0,042 & $-2,39$ & & & 0,035 & $-1,93$ & 0,00021 & 2,71 & 0,019 \\
\hline & P05090 & Apolipoprotein D & APOD & 405,37 & & 21,16 & 4 & 21,26176 & 5,15 & & & & & & & & & & & \\
\hline & P00441 & Superoxide dismutase [Cu-zn] & SODC & 213,66 & & 13,64 & 2 & 15,9259 & 6,13 & & & & & & & & & & & \\
\hline 2098 & P23528 & Cofilin-1 & COF1 & 121,84 & & 27,11 & 3 & 18,49066 & 8,09 & 0,0035 & $-2,13$ & 0,0054 & $-2,13$ & & & 0,0064 & $-1,74$ & & & \\
\hline 2108 & P00441 & Superoxide dismutase $[\mathrm{Cu}-\mathrm{Zn}]$ & $500 \mathrm{C}$ & 37,74 & & 23,38 & 1 & \begin{tabular}{|l|}
15,9259 \\
\end{tabular} & 6,13 & & & 0,033 & $-1,61$ & & & & & & & \\
\hline 2113 & P00441 & Superoxide dismutase [Cu-Zn] & SODC & 24,61 & & 9,09 & 1 & 15,9259 & 6,13 & 0,0069 & $-1,6$ & 0,0025 & $-1,71$ & & & & & & & 0,039 \\
\hline 2128 & P00441 & Superoxide dismutase [Cu-Zn] & SODC & 44,21 & & 9,09 & 1 & 15,9259 & 6,13 & & & & & & & & & & & 0,045 \\
\hline 2155 & P22392 & Nucleoside diphosphate kinase B & NOKB & 1035.06 & & 48,68 & 8 & 17,28694 & 8,41 & 0,025 & $-2,26$ & & & & & & & 0,046 & 1,78 & \\
\hline 2164 & P30044 & Peroxiredoxin-5 & PRDX5 & 332,87 & & 37,38 & 7 & 22,07255 & 8,70 & 0,045 & $-2,01$ & & & & & & & & & \\
\hline 2168 & P12273 & Prolactin-inducible protein & PIP & 1447,58 & & 66,44 & 9 & 16,5618 & 8,05 & 0,05 & 2,22 & & & & & 0,023 & 1,85 & & & \\
\hline 2173 & P30044 & Peroxiredoxin-5 & PRDXS & 346,33 & & 36,92 & 6 & 22,07255 & 8,70 & 0,027 & $-2,85$ & & & & & & & 0,038 & 2,07 & \\
\hline 2174 & P30044 & Peroxiredoxin-5 & PRDX5 & 556,23 & & 37,85 & 7 & 22,07255 & 8,70 & 0,013 & $-2,07$ & & & & & & & & & \\
\hline & P62937 & Peptidyl-prolyl cis-trans isomerase A & PPIA & 410,21 & & 60,00 & 9 & 18,00089 & 7,81 & & & & & & & & & & & \\
\hline 2185 & P62937 & Peptidyl-prolyl cis-trans isomerase A & PPIA & 69,14 & & 17,58 & 2 & 18,00089 & 7,81 & 0,021 & $-2,86$ & & & & & 0,017 & $-2,23$ & & & \\
\hline 2192 & P63241 & Eukaryotic translation initiation factor $5 \mathrm{~A}-1$ & IFSA1 & 201,06 & & 7,79 & 1 & 16,82141 & 5,24 & & & & & & & & & 0,018 & 3,57 & \\
\hline 2216 & $\begin{array}{llll}\text { P63241 } \\
\end{array}$ & Eukaryotic translation initiation factor $5 \mathrm{AA}-1$ & IFSA1 & 122,63 & & 26,62 & 3 & 16,82141 & 5,24 & & & & & & & & & 0,035 & 3,7 & \\
\hline 2279 & P07355 & Annexin A2 & ANXA2 & 185,98 & & 20,65 & 6 & 38,57982 & 7,75 & & & & & & & & & 0,0088 & $-2,39$ & \\
\hline 2282 & 001469 & Fatty acid-binding protein 5 & FABP5 & 648,31 & & 37,78 & 7 & 15,15455 & 7,01 & & & & & 0,038 & 2,69 & & & 0,037 & 2,58 & \\
\hline 2298 & Q05315 & Galectin 10 (Eosinophil lysophospholipase) & LEG10 & & 31,30 & 4,23 & $1(3)$ & 16,44222 & 7,37 & 0,029 & 4,04 & & & & & & & 0,037 & $-3,53$ & \\
\hline 2303 & P68871 & Hemoglobin subunit beta & HBB & 779,66 & & 82,31 & 10 & 15,98829 & 7,28 & & & & & & & & & 0,0098 & $-5,34$ & \\
\hline 2314 & P07737 & Profilin-1 & PROF1 & 1155,02 & & 61,43 & 9 & 15,04456 & 8,27 & & & & & & & & & 0,016 & $-1,82$ & \\
\hline 2318 & P06702 & Protein S100-A9 & S10A9 & 29,64 & & 11,40 & 1 & 13,23351 & 6,13 & & & & & & & & & 0,041 & 2,13 & 0,039 \\
\hline & 001469 & Fatty acid-binding protein 5 & FABP5 & 26,53 & & 14,81 & 2 & 15,15455 & 7,01 & & & & & & & & & & & \\
\hline 2361 & P68871 & Hemoglobin subunit beta & HBB & 296,82 & & 40,14 & 5 & 15,98829 & 7,28 & & & & & & & & & 0,044 & $-5,64$ & \\
\hline & P01037 & Cystatin-SN & CTTN & 233,53 & & 33,33 & 3 & 16,37734 & 7,21 & & & & & & & & & & & \\
\hline 2362 & P68871 & Hemoglobin subunit beta & HBB & 1402,12 & & 82,99 & 10 & 15,98829 & 7,28 & & & & & 0,043 & $-2,27$ & & & 0,021 & $-6,08$ & \\
\hline 2371 & P06702 & $\begin{array}{l}\text { Protein } 5100-A 9 \\
\end{array}$ & S10A9 & 230,90 & & 26,32 & 2 & 13,23351 & 6,13 & & & 0,026 & 5,9 & 0,0016 & 5,26 & 0,017 & 4,47 & & & \\
\hline 2387 & P06702 & Protein S100-A9 & $510 A 9$ & 1537,93 & & 49,12 & 6 & 13,23351 & 6,13 & & & 0,047 & 7,11 & 0,00023 & 8,71 & 0,005 & 7,01 & & & \\
\hline 2397 & P06702 & Protein $5100-A 9$ & S10A9 & 296,37 & & 44,74 & 4 & 13,23351 & 6,13 & & & & & 0,017 & 2,13 & 0,026 & 1,89 & & & \\
\hline 2405 & P06702 & Protein $5100-A 9$ & S10A9 & 1148,47 & & 48,25 & 7 & 13,23351 & 6,13 & & & & & 0.00018 & 4,92 & 0.023 & 1,6 & & & \\
\hline 2411 & P06702 & Protein $5100-A 9$ & $510 A 9$ & 296,37 & & 105,23 & 13 & 13,23351 & 6,13 & & & 0,0084 & 4,1 & & & 0,0016 & 4,27 & & & \\
\hline 2418 & P01040 & Cystatin-A & CTTA & 238,22 & & 76,53 & 6 & 10,99966 & 5,50 & 0,015 & 2,2 & & & & & 0,023 & 1,71 & & & \\
\hline & P06702 & Protein $5100-A 9$ & S10A9 & 178,22 & & 24,56 & 2 & 13,23351 & 6,13 & & & & & & & & & & & \\
\hline 2437 & P06702 & Protein S100-A9 & S10A9 & 6190,53 & & 71,05 & 14 & 13,23351 & 6,13 & & & & & 0,0097 & 2,14 & 0,033 & 1,88 & & & \\
\hline 2463 & P06702 & Protein $5100-A 9$ & S10A9 & 33,48 & & 11,40 & 1 & 13,23351 & 6,13 & & & & & & & & & 0,0098 & $-3,81$ & \\
\hline 2509 & P05109 & Protein S100-A8 & $\$ 10 A 8$ & 1716 & & 70 & 6 & 10,8 & 6,1 & 0,0075 & 2,43 & & & & & 0.011 & 1,96 & 0.015 & $-1,93$ & \\
\hline 2528 & P02768 & $\begin{array}{l}\text { Serum albumin } \\
\end{array}$ & ALBU & 7890,68 & & 70,94 & 46 & 69,3215 & 6,28 & & & & & & & & & 0,039 & $-1,8$ & \\
\hline & P54652 & Heat shock-related $70 \mathrm{kDa}$ protein 2 & HSP72 & 704,29 & & 18,15 & 11 & 69,97787 & 5,74 & & & & & & & & & & & \\
\hline 2532 & P02768 & Serum albumin & ALBU & 9339,81 & & 59,93 & 44 & 69,3215 & 6,28 & & & & & & & & & 0,021 & $-1,55$ & \\
\hline & P02790 & Hemopexin & HEMO & 1229,12 & & 34,42 & 16 & 51,64328 & 7,02 & & & & & & & & & & & \\
\hline
\end{tabular}

a) Raw mass spectrometry data was searched for protein identifications using both Mascot and Sequestpris spectrometry.

c) Peptides gives the number of high confidence peptides identified by mass spectrometry.

d) Molecular weight (MW) is in parenthesis, when it is not the size of the observed one on the gel. This can be due to cleavage to active chains or proteolysis. For immunoglobins Swissprot database gives only the constant region MW lacking the variable region.

e) $\mathrm{pl}$ is the theoretical isoelectric point of the protein.

Table S3

Table S3. IPA enrichment analysis of Top 5 functional categories of the identified 77 proteins

\begin{tabular}{l|l|l|l}
\hline Category & Function & Function Annotation & -value Molecules \\
\hline
\end{tabular}

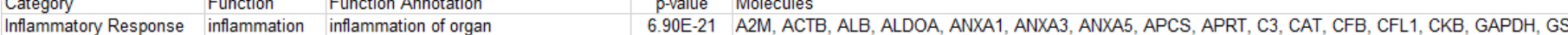

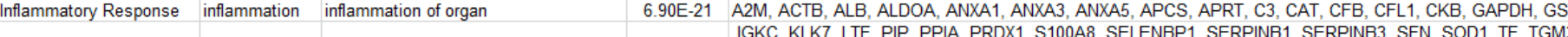

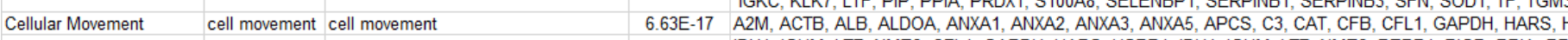
IDH1, IGHM, LTF, NME2, CFL1, GAPDH, HARS, HSPB1, IDH1, IGHM, LTF, NME2, PEBP1, PIGR, PPIA, PR S100A8, SELENBP1, SERPINA1, SERPINB1, SERPINB2, SERPINB3, SFN, SOD1, TPT1, WARS, YWHAE,

Free Radical Scavenging metabolism PRDX1, PRDX5, S100A8, SERPINA1, SOD1, TF, YWHAZ

Cell Death and Survival cell death cell death

A2M, ACTB AL ALDH1A1, ALDH3A1, ALDOA, ANXA1, ANXA2, ANXA5, APCS, APRT, C3, CAT CFB CF GAPDH, GSS, GSTP1, HSPB1, IGHM, IGKC, LTF, NME2,PEBP1, PIGR, PIP, PPIA, PRDX1, PRDX5, S100A SELENBP1, SERPINA1, SERPINB2, SERPINB3, SFN, SOD1, TF, TGM3, TPT1, TSTA3, YWHAE, YWHAZ

Immunological Disease allergy allergy ACTB, ALB, ALDOA, ANXA1, ANXA3, ANXA5, C3, CAT, CFL1, GAPDH, IGHM, KLK7, PPIA, PRDX1, S100A8, SELENBP1, SERPINB3, TGM3 
Table S4. Western blot analysis of nasal brush samples from 50 subjects who were excluded from proteomic analysis. The protein levels of Glutathione S-transferase 1 (GSTP1), Galectin 10 (LEG10), Protein S100-A9 (S10A9) and Calcyphosin (CAYP1) were assessed. Logarithmic transformation was used to attain normal distribution of the variables. The differences between the groups were analysed using the ANOVA and Fisher's LSD test for post hoc comparisons.

\begin{tabular}{|c|c|c|c|c|c|c|c|c|c|c|c|c|}
\hline & $\begin{array}{l}\text { Control } \\
\text { mean, } \\
\text { median } \\
\left(\mathrm{Q}_{1}-\mathrm{Q}_{3}\right) \\
\mathrm{n}=19\end{array}$ & $\begin{array}{l}\text { Protein } \\
\text { allerge } \\
n, \\
\text { mean, } \\
\text { median } \\
\left(Q_{1}-Q_{3}\right) \\
n=21\end{array}$ & $\begin{array}{l}\text { Isocyan } \\
\text { a } \\
\text { te, } \\
\text { mean, } \\
\text { median } \\
\left(Q_{1}-Q_{3}\right) \\
n=4\end{array}$ & $\begin{array}{l}\text { Weldin } \\
g, \\
\text { mean, } \\
\text { median } \\
\left(Q_{1}-Q_{3}\right) \\
n=6\end{array}$ & $\begin{array}{l}\text { P- } \\
\text { value } \\
\text { ANO } \\
\text { VA }\end{array}$ & $\begin{array}{l}\text { P- } \\
\text { value } \\
\text { Contr } \\
\text { ol vs } \\
\text { Protei } \\
\mathrm{n} \\
\text { allerg } \\
\text { en }\end{array}$ & $\begin{array}{l}\text { P- } \\
\text { value } \\
\text { Contr } \\
\text { ol vs } \\
\text { Isocy } \\
\text { anate }\end{array}$ & $\begin{array}{l}\text { P- } \\
\text { value } \\
\text { Contr } \\
\text { ol vs } \\
\text { Weldi } \\
\text { ng }\end{array}$ & $\begin{array}{l}\text { P- } \\
\text { value } \\
\text { Protei } \\
\mathrm{n} \\
\text { allerg } \\
\text { en vs } \\
\text { Isocy } \\
\text { anate }\end{array}$ & $\begin{array}{l}\text { P- } \\
\text { value } \\
\text { Protei } \\
\mathrm{n} \\
\text { allerg } \\
\text { en vs } \\
\text { Weldi } \\
\text { ng }\end{array}$ & $\begin{array}{l}\text { P- } \\
\text { value } \\
\text { Isocy } \\
\text { anate } \\
\text { vs } \\
\text { Weldi } \\
\text { ng }\end{array}$ & $\begin{array}{l}\text { healthy } \\
\text { persons; } \\
\text { Protein= } \\
\text { protein } \\
\text { allergen } \\
\text { group; } \\
\text { Isocyanate= } \\
\text { isocyanate } \\
\text { group; }\end{array}$ \\
\hline $\begin{array}{c}\text { GSTP } \\
1\end{array}$ & $\begin{array}{c}289414 \\
7 \\
170730 \\
7 \\
(30261 \\
7- \\
392298 \\
9)\end{array}$ & $\begin{array}{c}156538 \\
0, \\
970775 \\
(18219 \\
1- \\
211234 \\
3)\end{array}$ & $\begin{array}{c}445912 \\
9, \\
350318 \\
3 \\
(10263 \\
84- \\
884782 \\
1)\end{array}$ & $\begin{array}{c}304747 \\
2, \\
528945 \\
(13210 \\
3- \\
484621 \\
1)\end{array}$ & $\begin{array}{c}0.72 \\
8\end{array}$ & NT & NT & NT & NT & NT & NT & $\begin{array}{l}\text { Welding= } \\
\text { welding } \\
\text { group; } \mathrm{Q}_{1-}\end{array}$ \\
\hline $\begin{array}{c}\text { LEG1 } \\
0\end{array}$ & $\begin{array}{c}131978 \\
, \\
48965 \\
(33515- \\
111336 \\
)\end{array}$ & $\begin{array}{c}234375 \\
3, \\
432626 \\
(15369 \\
7- \\
202555 \\
7)\end{array}$ & $\begin{array}{c}108700 \\
8, \\
511138 \\
(20851 \\
6- \\
254137 \\
1)\end{array}$ & $\begin{array}{c}225335 \\
8, \\
381704 \\
(38876- \\
447394 \\
1)\end{array}$ & $\begin{array}{c}0.00 \\
1\end{array}$ & $\begin{array}{c}<0.00 \\
1\end{array}$ & 0.015 & 0.018 & 0.859 & 0.757 & 0.710 & \\
\hline $\begin{array}{c}\text { S10A } \\
9\end{array}$ & $\begin{array}{c}518310 \\
, \\
241829 \\
(62877- \\
338919 \\
)\end{array}$ & $\begin{array}{c}182793 \\
2, \\
539315 \\
(12710 \\
4- \\
233302 \\
4)\end{array}$ & $\begin{array}{c}269198 \\
8 \\
125442 \\
1 \\
(48019 \\
7- \\
634134 \\
7)\end{array}$ & $\begin{array}{c}269613 \\
9, \\
445668 \\
(20230 \\
2- \\
456006 \\
2)\end{array}$ & $\begin{array}{c}0.03 \\
7\end{array}$ & 0.031 & 0.020 & 0.065 & 0.259 & 0.693 & 0.500 & \\
\hline $\begin{array}{c}\text { CAYP } \\
1\end{array}$ & $\begin{array}{c}132029 \\
34, \\
464328 \\
5 \\
(12303 \\
31- \\
262818 \\
78)\end{array}$ & $\begin{array}{c}392414 \\
3, \\
281068 \\
7 \\
(12114 \\
75- \\
670278 \\
7)\end{array}$ & $\begin{array}{c}141750 \\
95 \\
608024 \\
1 \\
(10847 \\
16- \\
353603 \\
27)\end{array}$ & $\begin{array}{c}120813 \\
20 \\
144542 \\
8 \\
(38333 \\
3- \\
186223 \\
23)\end{array}$ & $\begin{array}{c}0.20 \\
7\end{array}$ & NT & NT & NT & NT & NT & NT & \\
\hline
\end{tabular}




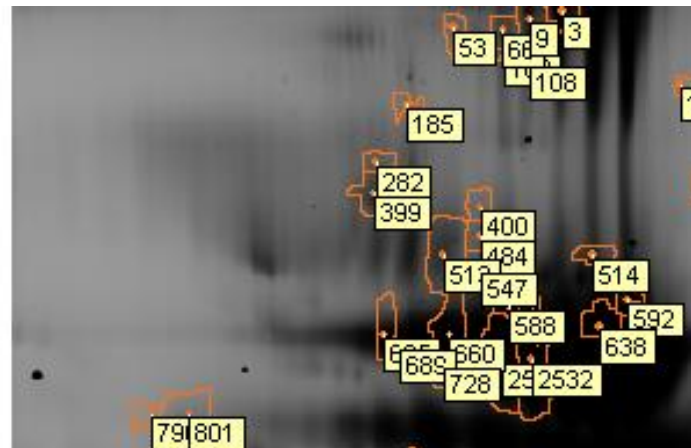

798001

$$
10370-1104
$$

101104

882

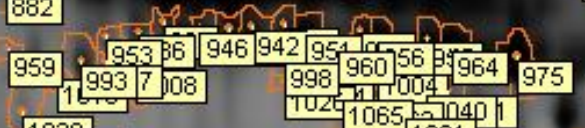

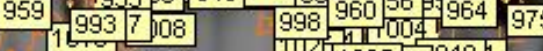
1039 1217

1269
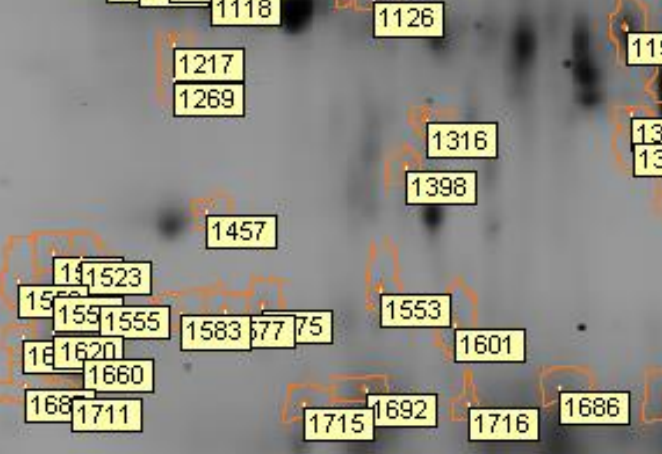

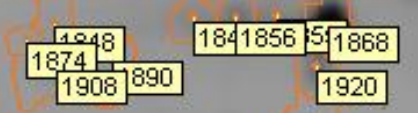

$$
19761978
$$

1998

2013

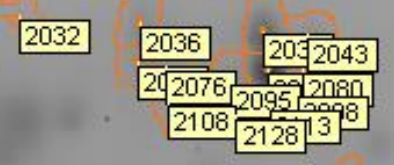

2168

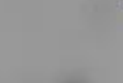

2192
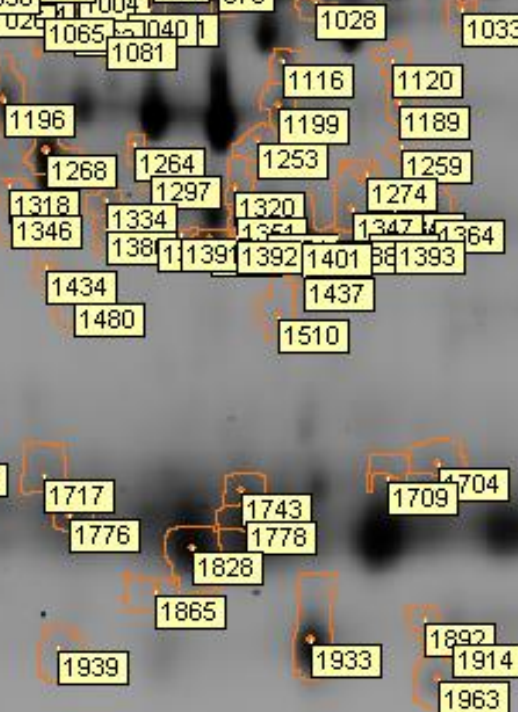

813

810

813
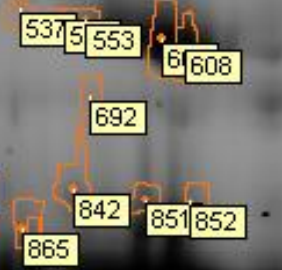

692

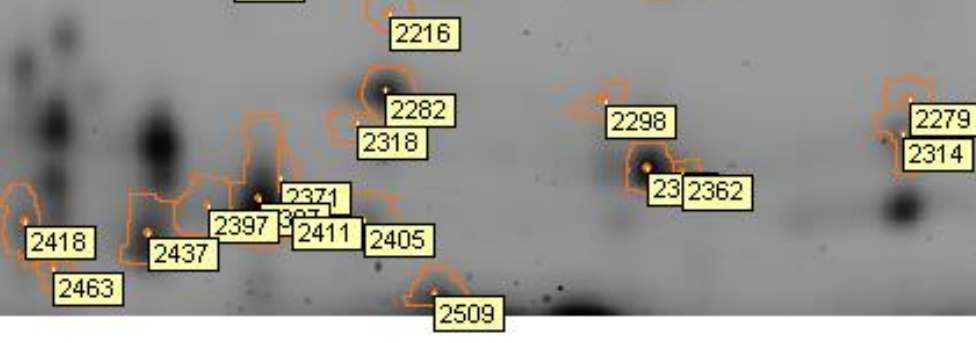

2155

216 $21 \sqrt[2185]{174}$

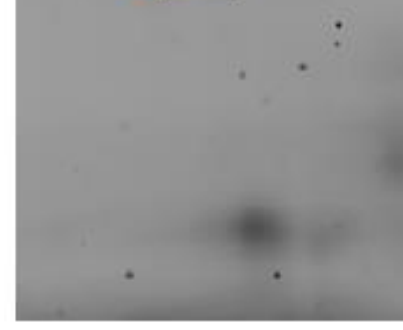

$\mathrm{pH} 3$

$\mathrm{pH} 10$

Figure S1 False colour two-dimensional differential gel electrophoresis (2D-DIGE) image of the identifi protein spots in the nasal brush samples. Spot numbers are marked on the gel image and protein identifications are listed in Supplementary file Table S2 according to the spot number. 
A.

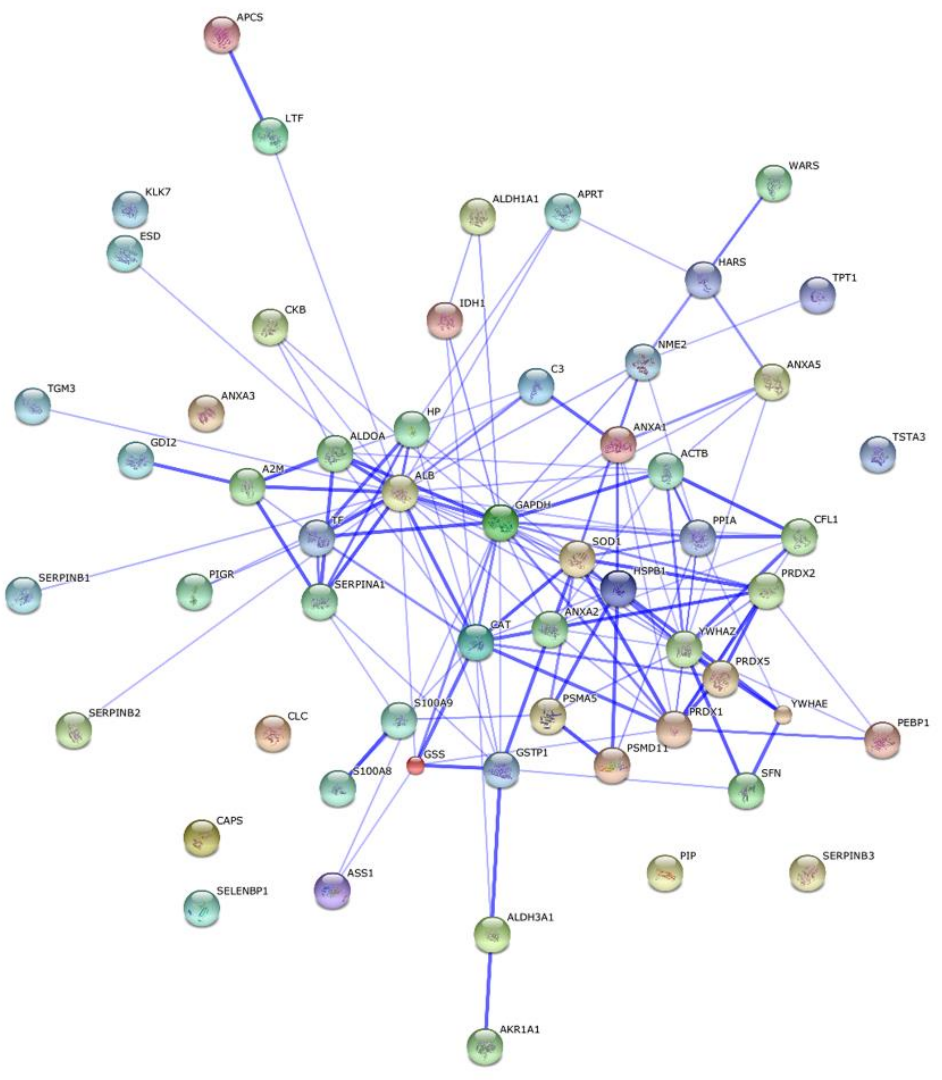

B.

$2^{\text {nees }}$

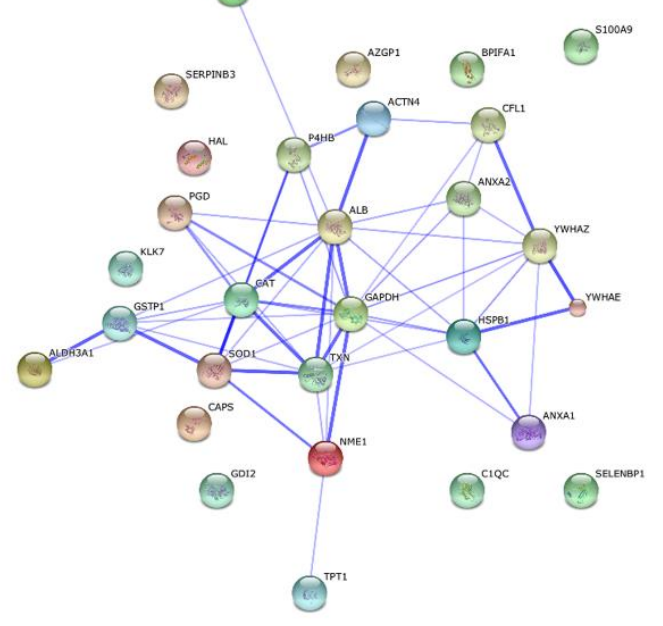

C.

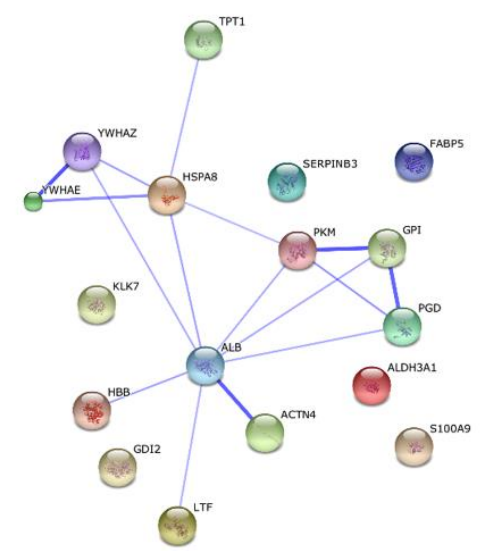

Figure S2 Protein association networks of the work-related asthma groups. Blue lines are confidence-based associations from the Str database for the identified proteins (Table 2) in the protein allergen (A), isocyanate (B) and welding (C) groups. Stronger association presented as thicker lines. Minimum required interaction score was 0,4 and all available STRING data sources were applied in the se 


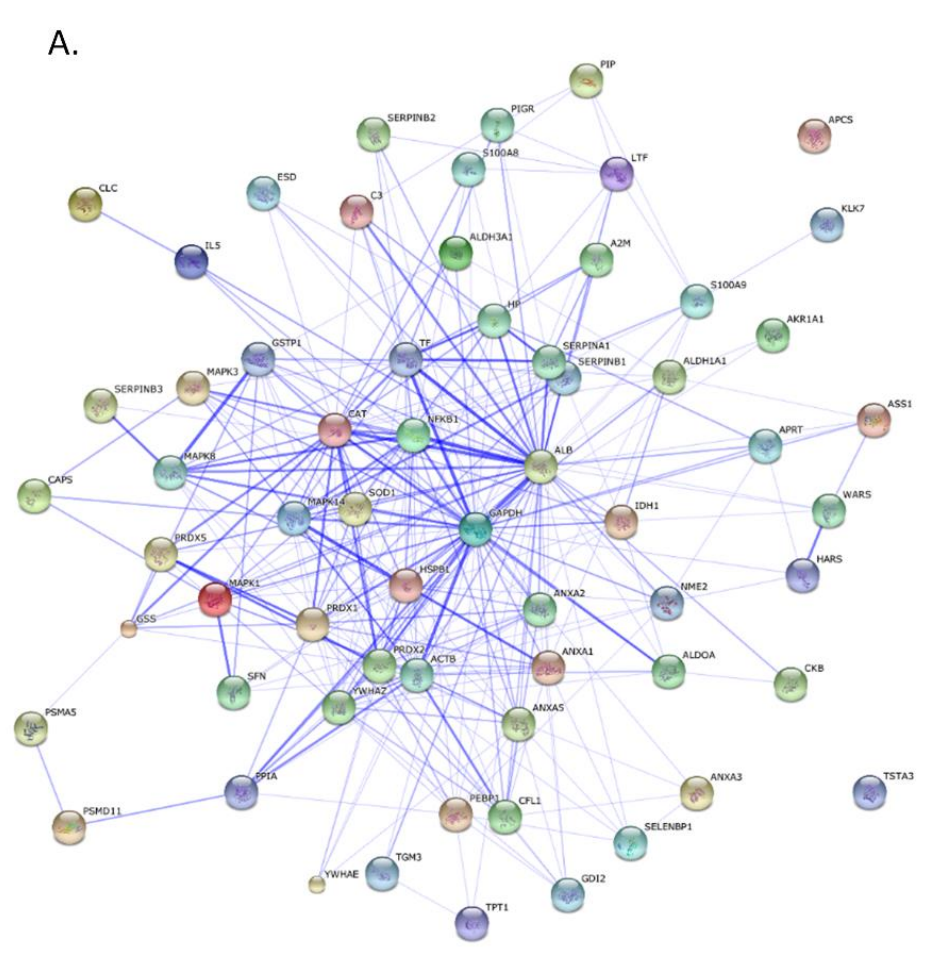

B.

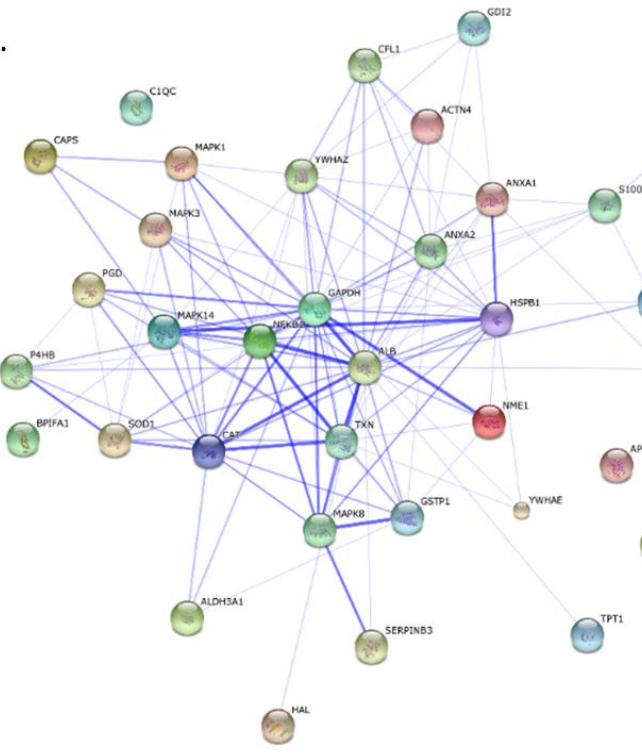

C.

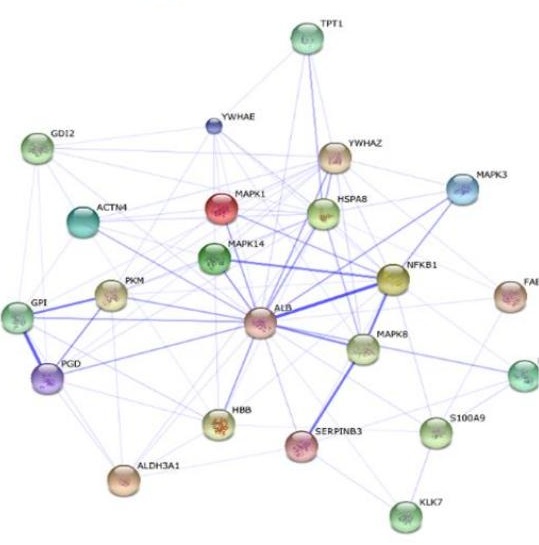

Figure S3 Protein association networks of the work-related asthma groups. Blue lines are confidence-based associations from the Strin database for the identified proteins (Table 2 ) in the protein allergen (A), isocyanate (B) and welding (C) groups. Stronger associations ar presented as thicker lines. Minimum required interaction score was 0,4 and all available STRING data sources were applied in the searc Mitogen-activated protein kinases (MAPK 1, 3, 8, 14), Nuclear factor kappa B (NFkB) and Interleukin-5 (IL-5) are included in the networ as they came up in individual protein network searches of the identified proteins and in IPA network searches (data not shown). 


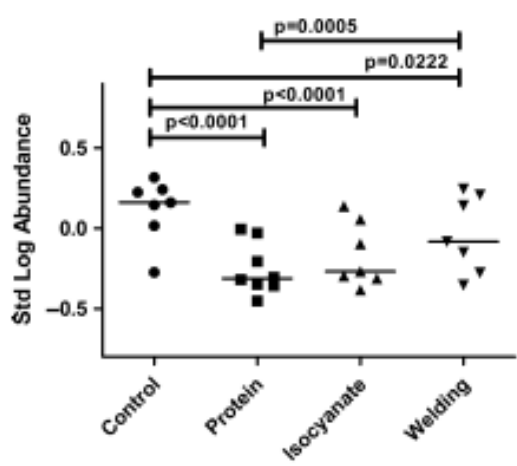

GSTP1

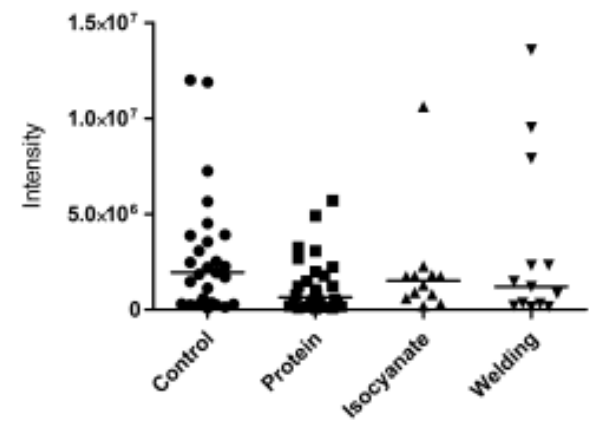

LEG10
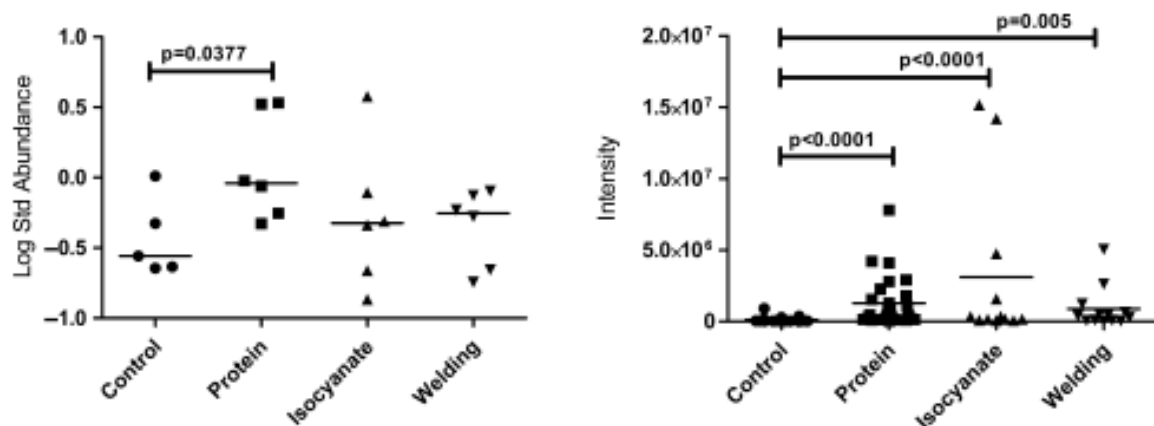

S10A9
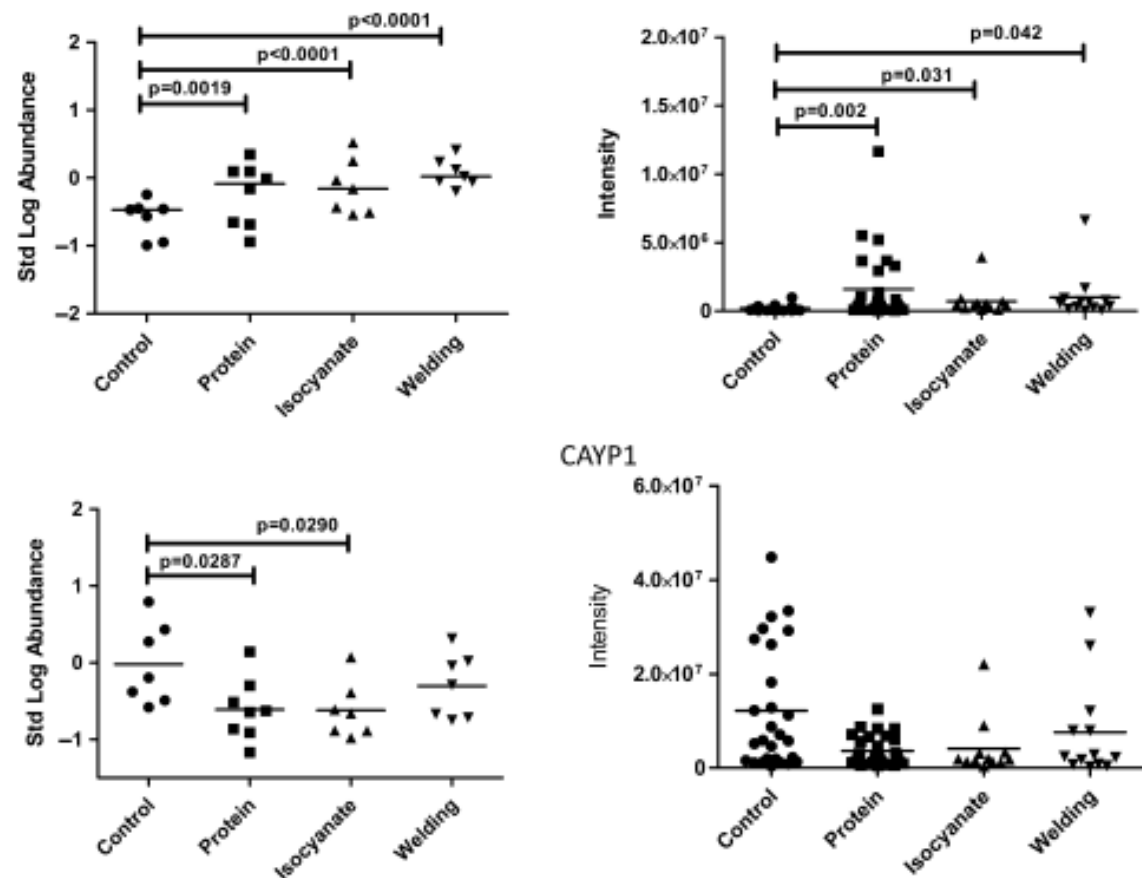

CAYP1

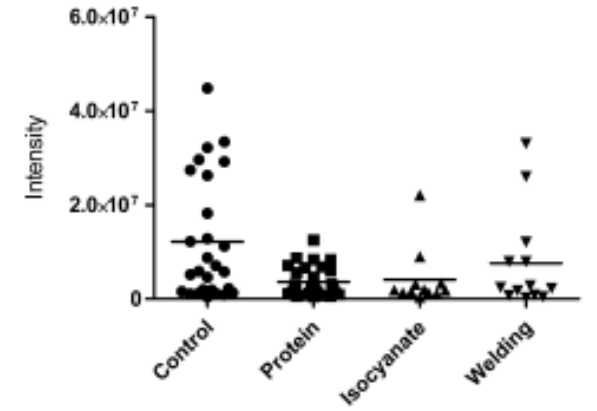

